\title{
Extended Review
}




\section{Hate on the Net: Extremist Sites, Neo-Fascism Online, Electronic Jihad by Antonio Roversi}

\section{Review by Louis Bailey}

Written by Italian sociologist Antonio Roversi and translated by Lawrence Smith, 'Hate on the $\mathrm{Net}^{\prime}$ falls within the area of criminology in its exploration of the Internet as a tool for inciting and promoting racially-motivated violence. Here, Roversi builds on his previous research into 'hooligan' football supporters and extreme right-wing groups in order to present the 'darker side of the net' $(p$. ix). To this end, the author is interested in how Italian Ultra, fascist and neo-Nazi groups self-organise in the age of the Internet. This is followed by an examination of how armed Middle Eastern groups utilise the Internet in a post-September 11th climate. Due to the unexpected death of the author soon after the book was written, the work represents the last of Roversi's ground-breaking forays into the sociology of the Internet. As such, it forms a seminal work for future research into the relationship between hate crime and the World Wide Web.

In the introduction, Roversi describes the methodology behind his research, which he summarises as mere 'desk' research lacking the more pro-active engagement of typical sociological research. However, such humbleness downplays the extent to which the author risked his own safety for the sake of his research and the urgent message communicated therein. According to David Nelken - the book's general editor -Roversi received numerous death threats soon after the book's release in Italy.

With unstated modesty, Roversi describes the emotional affects of conducting such harrowing and traumatic research, and the impossibility of remaining the detached observer. In this way, Roversi's explicitly subjective position can be interpreted as challenging more objective strands of ethnography, which extol distanced and thus allegedly more 'scientific' forms of critical evaluation but which, ultimately, lack the necessary insight which can only come with intimacy and empathy. Graphic descriptions of racial slurs and representations of racially-motivated violence are here interspersed with personal anecdotes and reflections, both in an attempt to communicate the otherwise incommunicable and to provide some light-relief. In so doing, Roversi clears a path for the reader to come face-to-face with dense material of a particularly cruel and obscene nature, material which is fuelled by a lack of respect for humanity and an excessive thirst for violence.

Despite the deeply sickening and horrific nature of the subject, Roversi avoids value judgements and is careful not to impose his own biases and opinions. Illustrative of this is his use of the term 'armed Middle Eastern groups' rather than 'terrorists' in keeping with the groups' own perceptions of their collective identity and codes of honour. Roversi's modest yet perceptive style is refreshing and serves as a necessary contrast to the heaviness of the material presented. To this end, Roversi manages to capture enough detail to successfully convey the gist of each website without dwelling on unnecessary and gruesome details merely for the sake of satisfying morbid curiosity.

In chapter one, Roversi explains the source of his intellectual curiosity pertaining to extremist sites. He describes how, whilst searching online for games created in Flash, he stumbled across a video in which a Middle Eastern Islamic group claimed responsibility for the September 11th events. Whilst anecdotes of this nature make for interesting reading, Roversi has a tendency to drift off subject. Tangential conversations about his internet usage and, in particular, his time spent in various chat rooms are rather long-winded and distracting, and, at best, contribute little to the overall argument.

Chapter two opens with Roversi 'outing' himself as a football fan and, reluctantly, as an ex-Ultra fan. He details the event of 29th May, 1985, a European Cup match between the Italian club Juventus and English team Liverpool in Brussels, to set the scene. On this day, a fatal error of judgement on the part of the organisers' led to Liverpool fans clashing with 'innocent' Juventus fans, resulting in a mass 
crush and the killing of thirty-nine spectators. The remainder of the chapter traces the rise of football hooliganism in Italy and the increasing stranglehold of Ultra groups in the area of football violence and racially-mounted violence more generally. There follows an examination of various websites representing Ultra groups, the content of which is divided into three elements - graphics and logos; photographs and videos; and 'the wall' - namely, the news feed. The resulting analysis focuses on notions of group representation and collective conviction. To this end, Roversi manages to avoid the more sensationalist aspects of some journalistic accounts, which reduce the Ultra group members to the status of idiotic barbarians. Instead, and especially worryingly, Roversi shows that this is far from the case, claiming that the groups' members are 'ordinary' citizens who study, go to work and live in the suburbs. He argues that it is the clandestine nature of the group which gives it its power.

The next chapter draws on earlier research into a group of young Nazi skinheads (or 'naziskin' as they are known in Italy) in Milan. The author describes a few nights spent 'socialising' with the group for research purposes. What follows is an insightful and, at times, humorous account of the group's behaviours, their style of dress and general outlook. We are presented with a group of insular and self-segregated youth who rely on 'cameratismo' (Italian for comradeship), nationalism and 'honour' as sustained through violence, xenophobia, racism, fascism and the easy creation of enemies. Commenting on the group's love of 'Oi!' and 'RAC' ('Rock Against Communism') music, Roversi notes that their pogo-style dancing seems like 'an enactment of a brawl to music' (p. 64). This brief ethnographic account provides an interesting snapshot of fascist and neo-Nazi youth groups in Italy and, by extension, serves as a useful introduction to the chapter's main focal point, namely fascist and neo-Nazi websites.

The remainder of chapter three examines a range of fascist websites. Roversi notes wryly that nostalgia is a common feature of the websites and that pictures of Mussolini and Hitler dominate. In addition, the majority of the websites present a revisionist history of the fascist period and not only deny the Shoah (namely, the extermination of Jews in Nazi concentration camps) but also present a range of conspiracy theories, some of which go as far to claim that Nazism was the result of a Jewish plot. Roversi's witty and insightful comments here serve to highlight the bizarre and hysterical nature of these websites, providing a compelling and accessible route into an otherwise harsh and difficult terrain.

The final chapter moves away from Italy altogether and goes on to discuss the use of the web by armed 'Middle Eastern groups', as they are here referred. This section suffers from a few limitations. Firstly, the author admits that he does not understand Arabic and that, as a result, he has been restricted to analysing websites which are in English. As such, the research presented draws on only a fraction of material pertaining to Middle-Eastern armed groups. Moreover, this material could be very different in tone from that presented by Arabic-speaking sites. Whilst the author claims to have enlisted the help of a translator for a few Arabic sites, he notes that something could have easily been lost in translation. Secondly, Roversi claims that he is not an expert in Middle-Eastern affairs. Whilst he tries to justify this point by claiming that as an expert in computer communications he seeks to only examine the role of the web in what he terms an 'unconnected war' (p. 97), there is no getting away from the fact that the current situation in the Middle East is central to the focus of this chapter.

In addition to the points notes above, it would have been valuable to gain an understanding of the author's ethnicity, race and cultural background. In the previous section, he was happy to 'out' himself as a football fan but for some reason does not 'out' his position in relation to the material discussed here. As a Westerner who has chosen to interpret these websites, Roversi undoubtedly would bring cultural and racial bias to bear on his readings and, by extension, analysis. Moreover, as one who is keen to maintain an emotional engagement and subjective positioning, the decision not to 'out' himself in the final section is an unfortunate oversight which is at odds with the original intentions for the book.

Roversi starts chapter four by providing detailed background information pertaining to Internet users in Islamic countries. The author then explains his research methodology and cites his 
frustration with the volatile nature of the websites which, he claims, have a tendency to disappear, sometimes altogether and sometimes reappearing elsewhere, under a new web address. As a result, the references provided are not necessarily accurate. However, despite these drawbacks, chapter four contains some fascinating insights, including a description of a video of bin Laden in Afghanistan. According to the author, the website contains two messages - one intended for 'Western' eyes and the other designed only for Muslim viewers. In the first instance, the leader wanted to show that he was still 'at large' and, thus, a threat to the 'Western' world. The latter demonstrates what the author terms the 'Muhammad paradigm', in which bin Laden drew on symbolic passages and descriptions from the Qur'an in order to align himself with the prophet Muhammad. Similarly, Roversi examines a video which is alleged to have been made on behalf of bin Laden and Al-Qa'ida following the September 11th attacks. According to Roversi, taken together, both videos are representative of the kinds of images employed by armed Middle Eastern groups online. Here, images of military heroism and victorious actions abound and are used as a means of boosting the morale of the civilian population. Such images are presented in stark contrast to the alleged inhumanity of the enemy and are shown alongside graphic images of civilian victims and, in particular, child victims.

Roversi goes on to describe the Al Fateh website, an especially disturbing website designed for children by the Palestinian group, Hamas. According to the author, illustrated children's stories preaching Islamic law and old Islamic fables are placed next to images of dead children and children soldiers. The author draws attention to the website's powerful manipulation of propagandist narratives, including martyrdom, in the weaving of children's fable and real-life war-zone. He sees them as brainwashing and warns of its disasterous consequences.

The book concludes with a discussion of the ways in which extremist groups, such as the neofascists and the Middle Eastern 'crusaders', have manipulated the Internet for their own violent ends. Roversi draws attention to the paradox of the Internet which, rather than representing a harmonised global community turns out to be nothing but a breeding ground for violence, conflict and division. In so doing, he shows how the Internet - a tool of mass communication and enabler of free speech - has been used as a mouthpiece for the promotion of racial disharmony, violence and war. As the examples here show, hate sites are neither sporadic nor hidden but, instead, are shown to be prevalent and indeed thriving in the present socio-political climate. As such, 'Hate on the Net' is a timely and extremely significant piece of research which bravely tackles the most pressing issue of our time namely, racial division and violence. Its message must not go unheeded and it is hoped that it will spur further research on the issue of extremist organising on the World Wide Web. 


\section{Book Reviews}

Louis Bailey

Bethan Harries 


\section{Reviews}

\section{ARTS, LITERATURE, SPORT AND MEDIA}

\section{AFRICAN WOMEN PLAYWRIGHTS}

\section{Ed. Kathy A. Perkins}

Publisher: Chicago, University of Illinois Press

Year: 2009

Pagination: 384pp

ISBN: 9780252075735

Price: $₫ 18.99$

This anthology, the first of its kind, celebrates the work of African women playwrights specifically and the creative output of African women generally. The editor links the need to create with a strong story-telling tradition in Africa, of which women have been a driving force historically. The plays in the collection aim to educate and heal, employing theatre as a vehicle for increasing awareness of the continent's socio-political problems. To this end, a range of controversial issues of particular social significance in Africa today, are explored including HIVIAIDS, female circumcision, women's rights, prostitution, cultural differences, and racial tension.

The collection comprises a total of nine plays from African women across twelve countries, including South Africa, Nigeria, Uganda, Zimbabwe, Kenya, Tanzania and the Ivory Coast. The writers were chosen from English-speaking countries in order to preserve the playwright's original voice. Also, only African women writers who live and work in Africa were selected rather than those who live and work abroad because of the lack of publishing opportunities for women in Africa. It is interesting to note that the women in the anthology consider themselves to be writers rather than playwrights, some of whom additionally identify as spoken word artists and film-makers. Included are a range of theatrical productions, such as radio dramas, staged prose, performance pieces, and group improvised projects. Each section contains background to the writer, excerpt from an interview with the editor, and the play's transcript.

The author claims that given the sheer number of society-imposed obstacles, it is amazing that African women playwrights have managed to find the time and space to create at all. However, this volume is a testament to the diverse and wide-ranging contributions of African women playwrights. And yet, the central issue remains - namely, that so few African women writers have been published and black female writers are severely underrepresented within school and university curriculums. A number of reasons are offered for this: that Africa has a stronger oral rather than written tradition; that written drama is considered to be leftover from missionaries during the colonial period; that publisher's lack the purchasing power to invest in fictional works; and finally, the very reality of gender discrimination in which girls are not encouraged to enter education or to pursue writing. In addition, there are numerous barriers pertaining to theatre, such as the fact that it is so time-consuming; it detracts from women's 'other duties'; and has a negative reputation in which a woman who is involved is considered to be 'loose'. The book aims, in part, to counter the stereotype of the 'primitive' African. Also relates to:

Culture, Identity, Gender and Relationships

Health and Social Care

THE ASSASSINATION OF THEO VAN GOGH: FROM SOCIAL DRAMA TO CULTURAL TRAUMA

\section{Ron Eyerman}

Publisher: Durham, Duke University Press

Year: 2008

Pagination: 232pp

ISBN: 9780822343875 
Price: $₫ 66.00$

This book examines the assassination of Dutch filmmaker Theo Van Gogh in Amsterdam, 2004, by a Dutch citizen of Moroccan descent. An anti-Western treatise was found on the body addressed to Ayaan Hirsi Ali, an outspoken proponent of Muslim womens' rights.

In chapter one, Assassination as Public Performance: The Murder of Theo Van Gogh, Eyerman explains the motive behind the murder. Van Gogh had directed 'Submission Part One', which was written by Ayaan Hirsi Ali, a Somali refugee and a member of the Dutch parliament. The film was highly controversial and both Hirsi Ali and Van Gogh received numerous death threats in the months following its release. Whilst Hirsi Ali was in hiding, Van Gogh refused to hide and went about his public routine. The murderer, Mohammed Boyeri, was arrested under the new anti-terrorism law in Holland.

In this part crime thriller, part cultural theory exploration, Eyerman examines possible explanations for the murder. However, in order to ascertain the murder's exact motives, Eyerman must first examine the social make-up of contemporary Dutch society and its sinister relationship with anti-Semitism and Islamophobia. There follows an analysis of Van Gogh's actions and influence as well as a detailed examination of the assassination as it reaches local and international artistic and Muslim communities.

In an interesting twist, Eyerman lends much discussion as to whether to classify the murder as a hate crime or as a media performance, moral panic or an artistic transgression on account of the sheer media attention and coverage generated. It is in the intersection of race relations and artistic interest that a social drama quickly becomes a cultural trauma and vice-versa. As such, Eyerman employs a range of analytic conventions through which to interpret the assassination - a performance, a mass media event, and a social/cultural drama.

Also relates to:

Culture, Identity, Gender and Relationships

Politics and Government

\section{BLACKFACE MINSTRELSY IN BRITAIN}

\section{Michael Pickering}

Publisher: Aldershot, Ashgate

Year: 2007

Pagination: 270pp

ISBN: 9780754658597

Price: $£ 55.00$

'Blackface Minstrelsy in Britain' reverses the commonly-held belief that blackface minstrelsy was an exclusively North-American phenomenon and that Britain merely imitated its legacy to instead focus on the cultural significance of British minstrel shows. In this way, the author shifts attention away from the United States to highlight the historical development of blackface minstrelsy in Britain in the nineteenth and early twentieth centuries.

Whilst Pickering acknowledges the ways in which British minstrelsy confirmed British colonialism, imperialism and White supremacy by presenting demeaning racial stereotypes of Black people, he nevertheless strives to understand and appreciate the theatrics of its performers. In a particularly unusual claim, Pickering alleges that minstrelsy had a significant impact on popular culture during the ragtime and jazz era and bemoans its recent disappearance from the archives of British popular culture. As a result, Pickering maintains an anachronistic position in relation to the subject and cites the need to acknowledge its artistic contributions in addition to exposing its racist legacy.

The book starts by tracing the impact of voluntary and involuntary migration on the tradition of blackface minstrelsy. Pickering goes on to highlight the ways in which minstrelsy was packaged as an alluring cultural commodity. However, putting aside the contribution of 'nigger' minstrelsy to facets of British racism during the Victorian period, Pickering instead focuses on 'its other interesting aspects', which are here summarised under the themes of 'theatrical conventions', 'symbolic 
meanings', and 'the politics of representation'. In so doing, the author outlines the development of minstrelsy on the professional stage and its resultant adoption within more casual forms of everyday culture. Chapter two examines the growth of minstrelsy as an established form of show business, and chapter three charts the rise of the amateur minstrel at popular seaside resorts.

Titled 'British Masks', chapter four presents an interesting social commentary about how the blackface mask cut across English nationalist conceit and, in particular, that all white people are honest and respectable in contrast to 'the black 'other". He goes on to expands upon the concept of the "black 'other" and the ways in which it has been used to affirm white racial identities and alleged 'superiority'. There follows a necessary critique of the ways in which minstrelsy has come to figure as one of the major sources of racist imagery, and how it has contributed to the development and functioning of British racial stereotypes. This aspect is explored in more depth in chapters six ('Black Clowns'), seven ('Early Ragtime') and eight ('Blackface Media').

Also relates to:

History

Migration, Immigration and the Refugee Experience

Politics and Government

THE BRAZILIAN SOUND: SAMBA, BOSSA NOVA AND THE POPULAR MUSIC OF BRAZIL Chris McGowan and Ricardo Pessanha

Publisher: Philadelphia, Temple University Press

Year: 2009

Pagination: 280pp

ISBN: 9781592139293

Price: $₫ 24.99$

An encyclopaedic survey of contemporary Brazilian music, charting current trends such as the development of Samba, the rise of female singer-songwriters and the mixing of Bossa with electronica. As such, it presents a revised edition. The book was first published in 1998 at a time when the Internet was just starting to reach a mass audience. Now, as a result of the development and spread of the Internet - including the rise of music downloading and social networking sites - Brazilian music has become more accessible and its influence more widely spread. This has meant that even the most obscure musicians have the potential for a global following.

The book aims to provide an interesting and informative introduction to Brazil's popular music and, as such, serves as a kind of musical guidebook. It highlights the centrality of music to the Brazilian way of life, showing how music has become a way of escaping the mundane reality of economic poverty. The introduction outlines the three key qualities of Brazilian music: the melodic qualities of Portuguese language, its lyrical poetry, and its Afro-Brazilian rhythms.

The opening chapter outlines Brazil's reputation as a symbol of fun and extravagance, citing the example of Carmen Miranda who sang Sambas and 'Marchas' in a string of Hollywood feature films and who has now, as a result, become a key cultural icon in North America and Europe. There follows a brief summary of the key musical trends in Brazil: firstly, the growth of samba, which was first recorded in the early part of last century and which came to underpin Rio's annual carnival celebrations; and secondly, the development of Brazilian percussion as an essential element of international jazz and popular recordings.

Chapter one provides a comprehensive background to the music of Brazil - charting the ethnographic background of the first Brazilians, the Portuguese conquest and the resultant mixing of European styles and people with Brazilian ways of life and, finally, the arrival of Africans in Brazil as a result of the Slave Trade. As a result, the authors claim, Brazil has a very mixed population. However, they point out that despite a general tolerance for interracial marriage, racism still persists within Brazilian society. At present, the Brazilian population is comprised of a population of Portuguese, Amerindian and African descent.

Chapter two charts the development of the Samba. However, rather than providing a rather cold and technical definition, the authors instead invoke an atmosphere of Samba. The remaining 
chapters follow the development of the Bossa Nova, which sprang from Samba; the rise of MPB namely, the 'Musica Popular Brasileira' (popular Brazilian music) - in the 1960s and 70s; Capoceira; instrumental music and Jazz; Rock and finally, Electronica and Hip-hop.

Also relates to:

Culture, Identity, Gender and Relationships

Economics and Globalisation

Science and Technology

\title{
DIVERSITY IN THE MEDIA: HISTORY OF THE CULTURAL DIVERSITY ADVOCACY GROUP TO THE MEDIA, 1992-2007
}

\section{Anver Jeevanjee}

Publisher: Waterside Press

Year: 2008

Pagination: $176 \mathrm{pp}$

ISBN: 9781904380429

Price: $\$ 39.95$ (USD)

This books documents the founding of the Cultural Diversity Advisory Group to the Media (CDAGM) - an independent voluntary group which was set up to ensure quality and diversity within British broadcasting. It was founded in response to the overwhelming racism within British media. Its founders were tired of the misrepresentation and negative stereotyping of Black and Ethnic Minorities (BME) by organisations such as the British Broadcasting Corporation (BBC). There follows an account of the group's interactions with the BBC and, in turn, their resistance to the group's pressing demands for racial diversity and a drastic change of attitude. In particular, the group sought better representation of and more opportunities for BME people.

The book starts by charting the group's aims and objectives, its members and its wider vision. Section one contains extensive archival information about the group's recommendations to the British media, including responses to the BBC Green Paper (Royal Charter Review) and the Communications White Paper. Also included within the archive are papers from various conferences, including the 'Building Participation Conference' and 'The BBC: An Ancient Heritage', and seminars, such as the 'Media Forum Policy Seminar' and 'Ethnicity and Media: Organisation and Staffing'. There follows copies of general correspondence between the group and the BBC.

Section two - 'Representations to the Media' - contains a letter to BBC South; the group's own ethnic monitoring exercise; and examples of complaints to the BBC and their responses. The next section details a selection of comments by individual contributors who are involved with the British media but who are not members of the group. Part four contains advice for dealing with the print media before going on to detail factual errors as well as negative and derogative portrayals of minority groups within the British press. The author believes that, in every instance, such misreporting and sensationalism is undertaken at the expense of Black and Asian readers. The book concludes with two essays by Jeevanjee - 'Europe's blatant arrogance towards other cultures' and 'Discussion on the necessity of a balanced presentation of diversity in programmes and the importance of promoting quality role models'.

Also relates to:

Culture, Identity, Gender and Relationships

\author{
EMBODYING AMERICAN SLAVERY IN CONTEMPORARY CULTURE

\section{Lisa Woolfork} \\ Publisher: Chicago, University of Illinois Press \\ Year: 2009 \\ Pagination: 248pp \\ ISBN: 9780252033902 \\ Price: $₫ 29.99$
}

'Embodying American Slavery' explores the re-enactment of American slavery within contemporary 
literature, films and performances. This serves two aims: firstly, to highlight the repercussions of cultural trauma in the contemporary moment and to address the prevailing cultural amnesia surrounding America's slave past. In so doing, the author highlights the ways in which both the protagonists and participants are forced to confront the reality of slavery, to physically 'go there' in order to really 'know' and 'understand'.

Central here is the notion of 'bodily epistemology', which refers to the corporeal dimensions of traumatic experience. In this context, it refers to the use of a contemporary body as a means of communicating a traumatic past episode. It emerges as a representational strategy in which the past is enacted by present-day protagonists in order to show that such events are neither dead nor past. Such re-enactments rely on the suspension of disbelief and time travel motifs for their effectiveness. However, the author claims that many people are resistant to these re-enactments due to denial, a sense of futility, and an emerging cultural amnesia. In this way, the separation between past and present is blurred in order to link America's history of slavery with continued apathetic attitudes towards trauma.

According to Woolfork, the history and repercussions of African American slavery serve to redefine notions of trauma, shifting attention away from the private into the public sphere. Viewed this way, the author's highlights the endurance of slavery's legacy, manifested, in part, through contemporary racism and anti-black sentiment.

Woolfork addresses the oversight that slavery is rarely mentioned in discussions of literary trauma theory. However, rather than force trauma theory to fit American slavery, she instead emphasises contemporary African American cultural performances of slavery which engage with trauma theory as their starting point. In this way, the author seeks to extend the work of a group of African American literary scholars who have engaged with psychoanalysis. Building on a theoretical framework of trauma theory, this book mixes psychoanalytic theory with cultural analysis and, in so doing, points to the wider relationship between psychoanalytic theory and African American life/ studies.

'Embodying American Slavery' starts by considering trauma and motifs of time-travel as informed though Octavia Butler's 'Kindred' (1979) and Haile Gerima's 'Sankofa' (1993). There follows a discussion of the use of bodily referents to communicate trauma. Chapter three details two films, 'Brother Future' (1991) and 'The Quest for Freedom: The Harriet Tubman Story' (1992), which target younger audiences and which present the slave past through the institution of incarceration. The following chapter considers the ways in which bodily epistemology emerges within contemporary reenactments of slavery. Here, the author considers the possibilities and limitations of re-embodying American slavery. Chapter five considers trauma theory as implied through the term 'maafa' - a Kiswahili word meaning 'disaster' and a vernacular theory and expression of slavery. Finally, chapter six analyses historical re-enactments of daily slave life at Colonial Williamsburg.

Also relates to:

Arts, Literature and Sport

Culture, Identity, Gender and Relationships

History

Politics and Government

\section{IRA ALDRIDGE: THE AFRICAN ROSCIUS}

\section{Ed. Bernth Lindfors}

Publisher: Rochester, University of Rochester Press

Year: 2007

Pagination: 288pp

ISBN: 9781580462587

Price: $₫ 30.00$

A collection of essays charting the life and career of African-American actor Ira Aldridge and his contribution to both British and European theatre. Known as the 'African Roscius', Aldridge was a widely celebrated Shakespearean actor in the nineteenth century. His acting career spanned a total 
of 43 years, during which time he amassed numerous awards, honours and other official modes of recognition. Despite becoming the 'most visible Black man in the world' by the mid-nineteenth century, Aldridge remains forgotten within the histories of British and European theatre. This anthology attempts to address this oversight.

Whilst the first section serves as a short biography, the second half of the book charts the critical reception of the theatrical contributions of Ira Aldridge. Included are early essays, dating from 1848 to the later 1860 , and more recent essays which present new biographical information about Aldridge. A discussion about his private life includes previously unpublished correspondence, such as love letters. There follows an examination of the ways in which theatre served as a medium for his pleas for racial equality and social justice. Particular attention is paid to his role in melodramas which centred on slavery and the slave debate. Other essays focus on his roles in Macbeth, King Lear and Othello as well as popular melodramas, such as 'The Black Doctor'. Discussion topics range from 'acting black' to performing 'whiteface' and note how Aldridge initially played "black role" but later performed 'whiteness'. The authors highlight how he countered the racial satire of black minstrelsy through his own creation of farcical black roles, which are here interpreted as confronting audiences with their own prejudices. In other words, it is claimed here, his acting forced critics to acknowledge the intelligence, sophistication and sensitivity of Africans and African Americans as a means of questioning their own white supremacist and racist beliefs.

To summarise, this book charts Aldridge's achievements on the British stage in light of racist responses from critics and audiences during debates about the abolition of slavery. Of particular interest for anyone interested in the local history of Manchester are Aldridge's appearances at antislavery events in Manchester.

Also relates to:

Culture, Identity, Gender and Relationships

History

Politics and Government

\section{THE LITERATURE OF THE IRISH IN BRITAIN: AUTOBIOGRAPHY AND MEMOIR, 1725 - 2001}

\section{Liam Harte}

Publisher: Basingstoke, Palgrave Macmillan

Year: 2009

Pagination: 256pp

ISBN: $978-1403949875$

Price: $₫ 55.00$

This is a collection of autobiographies and memoirs of writers of Irish descent, who lived and worked in Britain between 1700 and the present day. The volume contains extracts from a total of 63 works, much of which is either unpublished or out-of-print. The material itself is wide-ranging and consists of contributions of both known and unknown writers in a variety of styles and themes. The book aims, in part, to illustrate the social realities and shifting consciousness of Irish migrants in Britain over the last three centuries. To this end, attention is paid to the imagination, experience and personality of Irish migrant workers, as explored through the concepts of home, place and belonging.

The editor has taken the unusual, but politically important step, of including the work of migrant workers, also referred to here as 'worker writers'. Whilst he acknowledges that the use of the term 'migrant worker' detracts from focusing on the literary achievements of these writers, Harte nevertheless deems its interventionalist stance as a key priority. The bringing together of otherwise marginalised and neglected writers is key to challenging their previous omission within collections of Irish writing. Harte claims that critics have dismissed these writers because they do not possess the necessary autobiographical skills required for critical appreciation. Taking aim at such intellectual snobbery and attempting to widen the parameters of collections of Irish writing, this collection instead aims to make visible an otherwise absent literary contribution.

There follows a brief discussion of the barriers working class writers have faced - such as 
constraining working conditions (namely, the undertaking of long, laborious and exhausting work) and economic anxiety, both of which severely distract these writers from achieving their full literary potential. In addition, the prevailing anti-Irish sentiment over the centuries severely restricted employment opportunities and the social advancement for migrants.

Harte focuses on autobiographical writing as a means of giving voice to a group of marginalised and unknown writers. Moreover, he focuses on individual stories and experiences as a means of identifying an otherwise anonymous, and therefore easily dismissed, population. Challenging the homogenising tendency of any exploration of 'the Irish in Britain', Harte instead emphasises the multiplicity of positionings contained within this literary anthology and includes fragments of writing from labourers, intellectuals, tailors, politicians, journalists, domestic servants, street preachers, and chimney sweeps. As such, the material contained within the collection becomes a form of resistance writing through which socially displaced and disempowered subjects take charge of their representations and become autonomous agents of social/cultural and literary history.

Also relates to:

Economics and Globalisation

Employment

History

Politics and Government

\section{THE POWER OF THE ZOOT:YOUTH CULTURE AND RESISTANCE DURING WORLD WAR II}

\section{Luis Alvarez}

Publisher: Berkeley, California

Year: 2008

Pagination: $336 \mathrm{pp}$

ISBN: 9780520253018

Price: $\mathbf{2 2 4 . 9 5}$

'The Power of the Zoot' builds on in-depth interviews with former 'zoot-suiters' to examine the history of 'zoot suit' youth sub-culture in the United States during the 1940s. It analyses its music, fashion, language and social codes, the resulting survey presents a critical engagement with the politics of US urban culture post-World War II. The author focuses both on the stories of zoot suiters as well as the experiences of 'nonzoot' youth, parents and communities

The book starts by defining zoot suit culture in terms of its fashion: broad-rimmed hat, drape pants and oversized jacket for men, short skirt, heavy make-up and long jacket for women; and its music: Jazz, Swing and Jitterbug. However, Luis Alvarez is keen to point out that zoot culture is not just about style and appearance. Indeed, zoot culture, as it emerges here, is a form of social resistance and cultural subversion.

During the Second World War, zoot culture became a means of resisting the war effort and social expectations of passivity and conformity. As such, zoot culture emerged as a popular cultural phenomenon which challenged the boundaries of wartime national policy and American cultural identity. At a time of increasing xenophobia, the multiracial mix of zoot suiters - which included American American, African American, Nisci and White youth - challenged racial segregation and conformity. In contrast to prevailing attitudes that they were anti-American and undermined the effort to assimilate, zoot suiters in fact revealed the plurality of cultural identities. Moreover, rather than being the pejorative of the single-ethnic male, zoot culture was in fact a multi-racial and mixed gendered phenomenon. In the case of the latter, zoot suiters were regarded as an affront to the heroic masculinity of white sailors and soldiers both on account of gender transgressions - male zoot suiters were regarded as feminine because of their attention to fashion and female zoot suiters as masculine because of their seemingly aggressive behaviour - and on account of the inter-racial dating that occurred.

A major discrepancy which emerges is the difference between societal perceptions of zoot suiters as dangerous and anti-social deviants (a feeling that was heightened amidst a growing atmosphere of wartime defensiveness) and the zoot suiters' own attitude of needing to look and 
feel good as a means of claiming dignity within a culture which actively excluded and dehumanised them. As soon becomes apparent, zoot suiters were united by a critical stance towards authority, practicing their own cultural politics as a means of gaining self-respect and the respect of others. In this way, the author claims, zoot culture can be linked to contemporary Hip-hop style and its response to discrimination, lack of opportunity and police brutality.

Also relates to:

Arts, Literature and Sport

Criminal Justice and Racial Violence

History

Politics and Government

\section{SILENT GESTURE: THE AUTOBIOGRAPHY OF TOMMIE SMITH}

\section{Tommie Smith and David Steele}

Publisher: Philadelphia, Temple University Press

Year: 2007

Pagination: 288pp

ISBN: 9781592136407

Price: $₫ 12.99$

'Silent Gesture' centres on the moment in the 1968 Olympics in Mexico City, when athlete Tommy Smith and his team mate John Carlos raised a black glove fist upon receipt of their medals for first and third place respectively in the 200 metre sprint. The salute has been misinterpreted as signalling Smith's allegiance with the Black Panthers but Smith here dispels this myth, claiming instead that the gesture was representative of his life-long commitment to athletics, education and human rights. This biography is dedicated to the story of Smith's life and the series of events which lead to this iconic moment, charting the significance of the 'silent gesture' as a sign of social change in a turbulent history of race, politics and sports. Smith starts his biography by detailing the night of the Olympic stand on 16th October, 1968, and its significance in terms of his dedication to the Olympic Project for Human Rights. In this way, Smith's victory stand represented more than just winning the gold medal for a world-record sprinting time and instead provided him with a platform from which to make a stand against racial discrimination and injustice. And yet, for Smith, the occasion was not a particularly joyful one. He describes how, at that moment, he strongly believed that someone would end his life. He feared that, as a Black man from the United States who stood up for the human rights of his community, he was a prime target for racially motivated violence and hatred.

Smith goes on to detail the price he paid for his historic 'silent gesture', setting the scene against the backdrop of the rise of the Civil Right Movement in the US. Describing his awakening during an era that witnessed the assassination of Malcolm X and the defiance of Rosa Parks, Smith narrates how his lived experience of racism occurred simultaneously with learning about slavery. As a result, his first experiences of competing professionally coincided with his participation in human rights and Black rights marches. For Smith, the urge to run occurred in conjunction with the need to protest.

Describing his childhood of growing up poor in rural Clarksville, Texas, Smith makes links between struggling as part of a large family who were forced to work long and arduous shifts picking cotton in the fields, and his later life as a black man competing in the field of athletics in America in the 196os. There follows an account of Smith's move to San Jose State and his growing interest in running and training at the University sports track. During this time, Smith claims, it was the fortuitous encounter with an encouraging professor and supportive coach that enabled him to dedicate his life to professional sports. His dream was sealed with the meeting of his lifelong running partner, John Carlos.

Smith's biography closes with a sombre look at the political build-up to the Olympic victory stand. Here, Smith describes his decision to use the platform as a means of making a stand against injustice rather than a means of boycotting the Olympics altogether, as initially planned. Smith refutes the claim that the Olympic committee confiscated his gold medal; but claims the repercussions of the 
'silent gesture' were further reaching - culminating in taunts, death threats, professional rejection and community exclusion. However, despite the heavy price paid for making a stand, Smith continued to lead a successful and productive life in pursuit of racial equality and justice.

Also relates to:

Criminal Justice and Racial Violence

Education

History

Politics and Government

\section{STAGESTRUCK FILMMAKER: D.W GRIFFITH AND THE AMERICAN THEATRE}

\section{David Mayer}

Publisher: lowa City, University of lowa Press

Year: 2009

Pagination: $320 \mathrm{pp}$

ISBN: 9781587297908

Price: $₫ 42.70$

D.W. Griffith was an American actor-turned-filmmaker who, it is claimed here, was one of the first pioneers of modern film. From the 1890s through to the 1930s, he wrote and directed over 570 motion pictures and two stage plays. Prior to becoming a filmmaker he was a vaudeville performer. To this end, he worked as an actor between 1896 and 1907, starting his career in the Midwest before moving on to the East and then West coast of the US. Griffith entered motion pictures out of necessity, a means of maintaining a steady income and a way of continuing his professional standing as an actor. As a result, his films draw on a range of theatrical forms - from melodrama, comedy, minstrelsy, vaudeville and variety. This book is, in part, an exploration of the interaction of stage and cinema, and the influence of American theatre on Griffith's filmic output. Rather than presenting a biographical account of Griffith, the author instead charts his impact on screen acting and staging. As such, the book presents a socio-historical account of the impact of Griffith and his work on the American cultural imagination.

This is a critical study of D.W Griffith and his contribution to modern film. The author responds to well-noted allegations of racism pertaining to Griffith. This is followed by an in-depth discussion about his obsessive interest in ethnic and national 'difference' as related to African Americans, Native Americans, Chinese labourers, Jews, Gypsies, Italians, Hispanics and Mexican migrants. Mayer examines the nature and origin of Griffith's fascination with 'otherness' and the place of immigration and slavery in early modern American society.

According to Mayer, Griffith's 1915 film 'The Birth of a Nation' is indicative of America's cultural and political climate in the early twentieth century. Whilst he acknowledges the film to be racist by contemporary standards, the author urges the reader to understand the racial climate of the early twentieth century and the fact that early audiences would not have necessarily reacted in the same way. To this end, much of the book is dedicated to contextualise the film in an effort to present a more nuanced reading of the film's intentions and reception. For example, Mayer claims that Griffith's presentation of African Americans as lazy, ignorant, drunk, deviant and savage is in keeping with prevailing Southern attitudes as a response of the 'demoralised' South to the Post Civil War Reconstruction. By turns, Mayer traces the gradual disappearance of racial 'otherness' in Griffith's films as connected to an increased awareness of tolerance and assimilation as desirable national goals.

Also relates to:

Culture, Identity, Gender and Relationships

History

Migration, Immigration and the Refugee Experience

Politics and Government 


\section{CRIMINAL JUSTICE}

\section{HATE CRIME AND THE CITY}

\section{Paul lganski}

Publisher: Bristol, Policy Press

Year: 2008

Pagination: 168pp

ISBN: 9781861349392

Price: $₫ 21.99$

'Hate Crime and the City' counters the notion that all racially-motivated hate crime is pre-mediated by deprived and hate-filled bigots to instead make a case for the ordinariness of hate crime offences which, the author claims, are mostly undertaken by ordinary people within their everyday lives. In so doing, the book aims to both further conceptual understanding and to apply empirically-grounded analysis with regards to incidents of 'hate crime'.

Chapter one - 'A victim-centred approach to conceptualising 'hate crime' - explores the conceptual complexity of the term 'hate crime', presenting a victim-centred approach in order to better understand its conceptualisation. There follows a look at the normality of everyday 'hate crime' and how 'hate crime, far from being undertaken by convicted offenders, is often undertaken by friends, work colleagues, family and neighbours of the victim. In this sense, chapter two focuses on what the author terms the 'missing link' between background structures of bigotry and offenders' actions which translates into ordinary people ('people like us') reacting to situational events and acting out values which permeate the social structure. By focusing on the situational dynamics of 'hate crime', Iganski shifts our attention away from abstract notions of 'hate' and 'crime' and instead turns our attention towards the experiential, namely 'hate crime' as it is motivated and experienced.

'The spatial dynamics of everyday 'hate crime' forms the topic of chapter three. The chapter is structured around the case study of London, chosen precisely because it is both the most ethnically and culturally diverse city in the UK yet also the UK's capital of 'hate crime'. Drawing on previously unpublished police data pertaining to 'race hate' incidents in London, the chapter details filed reports of 'hate crime' incidents around the city. The resultant statistical trends are measured through an 'inter-group friction' hypothesis - whereby 'race-hate crime' is proportional to the amount of intergroup contact in each locality. In addition, results are also examined in relation to a 'power differential' hypothesis, which proposes that the rate of 'race-hate crime' is higher in areas where minority communities account for a small proportion of the population. Together, these trends inform 'hot spot' areas of everyday 'hate crimes'.

Whilst chapter four focuses on tensions produced by liberalist attitudes towards criminalising 'hate', chapter five makes a case for a victim-led approach to considering 'hate crimes' within the criminal justice policy process. Whilst the former warns about giving harsher penalties to perpetrators of hate-crime compared with other violent acts, the latter highlights the need for a multi-faceted consideration of the demographics of 'hate crime'.

The book concludes by arguing for the development of 'hate crime' studies within the UK, making a case for the potential of 'hate crime' analysis within a scholarly domain. Such a venture would, the author argues, compliment current policy reports and national police reporting on 'hate crime' incidents.

\section{CULTURE AND IDENTITY}

\section{AMERICAN CHRISTIANS AND ISLAM: EVANGELICAL CULTURE AND MUSLIM'S FROM THE AGE OF TERRORISM}

Thomas S. Kidd

Publisher: Princeton, Princeton University Press

Year: 2009 
Pagination: 224pp

ISBN: 9780691133492

Price: $\mathbf{f 2 0 . 9 5}$

Investigates the historical background which gave rise to the denouncing of Islam as "demonic" by many of America's Christian evangelicals following the September 11 terrorist attacks. Written by a practicing Christian, the book is concerned about the ways in which American Christians have written about Islam and how current attitudes and beliefs have been informed through centuries of resistance to Islam.

Chapter one considers the early Anglo-American attitudes towards Islam and the ways in which Islam was used within Intra-Protestant theological debates. Charting the threat of Barbary piracy following the capture of European Christians in North Africa, early American Christians aspired to convert Muslims to ways of Protestant Christianity. Building on this, chapter two draws on this important historical context to highlight how both Barbary piracy and Islam-as-theological challenge have formed the foundations of an American Christian fear of Islam.

In chapter three, Kidd charts how the growing clash between Islam and Christianity resulted in the sending of American missionaries to Muslim lands during the nineteenth century, marking the beginning of the first large-scale British and American missionary movement. This resulted in increasingly popular narratives about alleged incidences of Muslim conversion, which were filled with exaggerated claims. Picking up this deceitful thread, chapter four highlights the American Christian's growing frustration about the lack of missionary success among Muslims during the late nineteenth and early twentieth centuries. Attempts to convert Muslims to Evangelism represented a subsidiary goal of the missionary movement's motivation to spread the word of Christ. However, such attempts to convert Muslims to another faith were undertaken in vain.

Chapter five takes a sideways glance at the disintegration of the American Missionary Consensus during the 1920 s and 305, and the resulting rise of conservative missionaries whose sole aim was to convert rather than to provide social aid or education. Following on from this, chapter six examines the situation in the U.S post Second World War. Here, an increased Muslim presence, both as a result of American-born Muslims and, after 1965, Muslim immigrants and students coming to the U.S from overseas. Kidd describes the mixed reactions of the more conservative American Christians, some of whom claimed that 'domestic Muslims' represented a threat whilst others insisted that they could be saved through Christian conversion.

In a rather dramatic turn, chapter seven examines the effects of the collapse of the older American Christian system and the renewed interest in the Evangelical conversion of Muslims during the 1960s. The book concludes with an investigation into the effect of the September 11th attacks on American Christian views of Islam, which resulted in a renewed interest in Muslim conversions in an attempt to end Islam. As a result of this, recent developments in literature place Islam at the centre of end-of-the-world prophecies, in which Muslims are represented as figures of Anti-Christ and Islam depicted as "demonic". In citing the American Evangelists' dealings with Islam, Kidd warns of the dangers and difficulties of maintaining exclusive religious views in a pluralist global world.

Also relates to:

Arts, Literature and Sport

History

Migration, Immigration and the Refugee Experience

THE ARYAN JESUS: CHRISTIAN THEOLOGIANS AND THE BIBLE IN NAZI GERMANY

Susannah Heschel

Publisher: Princeton University Press

Year: 2008

Pagination: $384 \mathrm{pp}$

ISBN: 9780691125312

Price: $\mathbf{2 0 . 9 5}$

'The Aryan Jesus' charts how, during the Third Reich and fuelled by anti-Semitism, German Protestant 
theologians redefined Jesus as an Aryan and, by extension, Christianity as a religion at war with Judaism. The result - the founding of the 'Institute for the Study and Eradication of Jewish Influence on German Religious Life' (1939-1945) in Eisenach, Germany - is the subject of this book. Key here is an examination of how the Institute became one of the most important propaganda organs of German Protestantism, contributing to the production of a Nazified Christianity which placed antiSemitism at its heart. There follows an analysis of the ways in which the Institute contributed to and actively promoted Hitler's attempts to eradicate all Jews.

In the pages that follow, the author presents a detailed account of the aims, vision and structure of the Institute. Therein it is revealed that the Institute was founded to create a unified, national German Church, which transcended Protestant and Catholic divisions in order to redefine Christianity as a Germanic religion. To this end, it aimed to promote the notion that Jesus was not a Jew and had fought to destroy Judaism but failed. The Institute regarded Germany's task to continue Jesus' own struggle against Jewishness. Central to this premise was the notion of the Aryan as an inner spirit which was simultaneously powerful yet also vulnerable and in need of protection from the degeneracy of non-Aryans, especially Jews. Its main theology was to care for that spirit and the Institute developed new biblical interpretations and liturgical means for this purpose.

The book charts how the Institute came to represent a thriving achievement of the German Christian Movement, achieved, in part, through the pro-Nazi faction of the German Protestant Church. To this end, the author creates an important discussion, which centres on the following questions: 'Why was it so easy to racialise Christianity?'; 'what makes anti-Semitic ideas so appealing to Protestant theologians in Germany during the first half of the twentieth century?'; and 'what are the affinities between theology and racism?'

\section{Also relates to:}

History

Politics and Government

\section{BLACK BEAUTY: AESTHETICS, STYLISATION, POLITICS \\ Shirley Anne Tate}

Publisher: Aldeshot, Ashgate

Year: 2009

Pagination: $188 \mathrm{pp}$

ISBN: 9780754671459

Price: $₫ 50.00$

Here, Shirley Anne Tate undertakes a range of interviews with British women of Caribbean descent in order to gain further insight into their relationship to ideals of Black beauty. Such an inquiry is motivated by the need to question the cultural politics of racial hierarchy and the consequent privileging of White beauty as an ideal state. At the same time, Tate also destabilises given 'truths' pertaining to Black beauty and takes issue with the essentialist tendencies of shaped theoretical debate pertaining to Black beauty. To this end, Tate employs difference as the basis for destabilising the alleged 'certainties' of certain strands of anti-racist, Black atlantic and feminist thought.

Attention is paid to the ways in which Black women negotiate dominant understandings, stereotypes and assumptions of beauty. Working within a theoretical framework of performativity and stylization, a key concern is how these women both work with and against a range of paradigms relating to beauty. Paying close attention to the nuances and textures of skin and hair, Shirley Anne Tate focuses on the ways in which women both embody and perform different kinds of Black beauty. In this sense, Black beauty emerges as a result of the interaction of the performative with aesthetics, stylization and politics, as informed through beauty ideals, feminist intellectualising and diasporic knowledge.

Tate takes issue both with Eurocentric philosophising around the nature of beauty as well as black authenticity versus White winnable debates within Black communities. For Tate, the latter positioning is problematic as it revolves around whiteness. Instead, Tate highlights the variety to be found within Black beauty in order to decentralise the position of White beauty as a marker against 
which Black beauty is judged.

The resulting chapters examine Black beauty through concepts of shame, melancholia, hybridity, mimicry and performativity and look towards contemporary anti-racist aesthetics in its investigation of the racial hierarchies of hair and, in particular, debates surrounding the natural/ unnatural hair binary. Later, skin replaces hair as the focus for a discussion about the melancholia of Black beauty and the role of shame in beauty recognition. There follows a discussion of Black diasporic beauty politics as triggered through a disidentification with Eurocentric beauty ideals and the resultant need to return to the roots of one's homeland, as real or imagined. The remaining chapters explore the interaction of beauty, ugliness and shame as related to one's sense of self, and how shame and melancholia become the motivators of change. The book concludes with a discussion of the necessity of a wider and more inclusive Black beauty citizenship in order to enable a Black antiracist feminist politics to continue.

\section{Also relates:}

Health and Social Care

Politics and Government

\section{CHINESE AMERICANS AND THE POLITICS OF RACE AND CULTURE}

\section{Eds. Sucheng Chan and Madeline Y. Hsu}

Publisher: Philadelphia, Temple University Press

Year: 2008

Pagination: 288pp

ISBN: 978-1592137527

Price: $₫ 66.00$

This is a collection of essays by historians of Chinese America. In the book's introduction, the editors chart the formation of Chinese American Studies which, they claim, is in keeping with cultural history rather than social history on account of the emphasis on personal life stories and experiences rather than objective statistical analysis. Here it is claimed that although ChineseAmerican Studies represents a popular field of study, it raises a number of problems outside of academia on account of the 'nativist' split of 'Chinese' versus 'American'. However, the editors argue that one way of avoiding this pitfall is to embrace the transformative aspects of these cultural processes rather than be resigned to notions of an allegedly unchanging continuity. Chapter one charts the significance of the Tape versus Hurley case, which upheld the rights of Chinese American children to a public school education during the exclusion era (1882-1943). Of interest here are the ways in which educational access highlighted the inherent contradictions of claiming a Chinese American positioning. In chapter two, attention is paid to the activist organising of leftist and communist Chinese immigrants within the US communist movement from 1927 to 1933. Chapter three shows how China's war against Japan in the 1930 and 40s challenged American perceptions of China and Chinese Americans. This resulted in the elevation of Chinese Americans from a racially inferior position to the status of potential American citizens. In keeping with this, chapter four examines how Chinese Americans became working allies during the Second World War.

In a particularly humorous take on Chinese American nationality, chapter five traces the shift from the racialisation to the ethnicization of Chinese Americans during the Cold War era and the resulting commodification of Chinese culture as palatable cuisine. Chapter six highlights the significance of the 'In Search of Roots' program at the Chinese Culture Center in San Francisco (cosponsored by the government of the People's Republic of China) in the identity formation of ChineseAmerican students. Lastly, chapter seven is an ethnographic study of the Changle ren (Changle people) from the Fuzhou district in the Fujian province, China, who have been negatively stereotyped as illegal immigrants due to sensationalist media coverage of efforts to smuggle Chinese people into the US.

\section{Also relates to:}




\section{Education}

History

Migration, Immigration and the Refugee Experience

Politics and Government

\section{CONTEMPORARY BRITISH IDENTITY: ENGLISH LANGUAGE, MIGRANTS AND PUBLIC DISCOURSE}

\section{Christina Julios}

Publisher: Aldershot, Ashgate

Year: 2008

Pagination: 210pp

ISBN: 978-0754671589

Price: $₫ 55.00$

Here, Julios examines the centrality of the English language to both the construction of modern British identity and to the acquisition of British citizenship before moving on to highlight the dominance of English both nationally and internationally.

Part one-Language and Identity - summarises recent debates about definitions of British identity and citizenship before concluding that, in both cases, the acquisition of English language is central. There follows a look at the spread and influence of the English language - the global language - through the processes of colonisation, de-colonisation and globalisation. A case in point is the promotion of the English language through the World Wide Web, which can be interpreted as yet another example of the continued legacy of the British Empire.

This section moves on to explore the ways in which different governments have addressed the policy dilemma of mono and bi-lingualism. Charting the impact of immigration on language and, consequently, within policy decision-making, Julios notes some interesting points of consideration. For example, she claims that, over the past fifty years, governments have oscillated between promoting multiculturalism on the one hand, and reinforcing a majority language, on the other. According to Julios, this has mixed results. In the first instance, cultural difference and diversity is preserved, in one moment, but then consequently assimilated within the dominant culture. However, Julios reminds us that, despite these conflicts and contradictions, the majority (dominant) language nevertheless absorbs 'outside' cultural influences and language. This has its benefits but can also come with many shortfalls, as the author goes on to explain at length.

Part two - Migrants and Public Discourse - takes as its starting point the fact that the last one hundred years have seen the emergence of a distinctive British identity which has been modelled on an English-speaking white Anglo-Saxon Protestant ideal. As a result, claims Julios, the English language has become the British Empire's ultimate tool of cultural domination. This forms the backdrop against which Julios charts the changing notion of Britishness from the 1900 s to the present as a result of the impact of the New Commonwealth, the passing of the Aliens Act, the British Nationality Act and the Education Act in the early part of last century, the New Commonwealth Immigration Act and the Race Relations Act in the latter part of that century. There follows a look at the contemporary discourse of integration, as informed through the passing of the Community Cohesion Act.

Lastly, summarising the components of national identity into culture, demographics, economics, politics and mythology, Julios examines the 'challenge' of migration. Examining the notion of 'minority' and 'majority' in relation to both native and immigrant status, Julios focuses on the ethnic immigrant communities which have formed as a result of recent migrating population movements. Here, particular attention is paid to non-English speaking settlements in Britain.

\section{Also relates to:}

Arts, Literature and Sport

Economics and Globalisation

Education

History

Migration, Immigration and the Refugee Experience

Politics and Government 


\section{GENDER VIOLENCE: INTERDISCIPLINARY PERSPECTIVES}

\section{Eds. Laura L. O’Toole, Jessica R. Schiffman, Margie L. Kiter Edwards}

Publisher: New York, New York University Press

Year: 2007

Pagination: $560 p p$

ISBN: 9780814762103

Price: $\$ 30$ USD

This is the second and revised anthology on 'Gender Violence: Interdisciplinary Perspectives'. This collection of essays explores the spectrum of gender violence - from social commentaries on rape, battering, incest, sexual harassment, child abuse and murder, to in-depth examinations of inter-ethnic conflicts and government-sanctioned sex industries. At the root of each example of gender violence is an extreme application of social control - whether by physical force, harassment, ethnic cleansing, or a psychological threat. In this sense, gender violence can be interpersonal or institutional, intimate or state-controlled. It takes many forms - from controlling the public behaviour of men and women to transphobic hate crime and assault (namely the fear of and violence towards people who are transgendered). Gender violence, claim the editors, is pervasive and is central to the current social system.

The book takes an interdisciplinary approach, encompassing both academic and cultural perspectives, to explore the ways in which interpersonal relations and social institutions contribute to the social construction of gender and to gendered violence. Whilst its primary focus is to document the violations of women, the book also considers the more general link between the social construction of gender and gender-related violence. In this way, it also includes essays examining the violence against children, men, and trans people.

The anthology is divided into three parts. The first section - 'Roots of Male Violence and the Victimization of Women' - presents a socio-historical exploration of gender violence, firstly, from a general world-view and, secondly, from a specifically North-American viewpoint. This translates to an exploration of the conditions that give rise to male violence, and the widespread cultural and historical trends of patriarchal domination and its affect on gender relations. Section two - 'Forms of Sexual Coercion and Violence' - breaks down the facets of gender violence under the headings 'Sexual Harassment', 'Rape', 'Domestic Abuse', 'Children and Gender Violence', and 'Pornography and Prostitution'. The third and final section - 'Creating Social Change' - contains important strategies for transforming gender relations and ending gender violence.

\section{Also relates to:}

History

\section{'GENDERING MIGRATION: MASCULINITY, FEMININITY AND ETHNICITY IN POST-WAR BRITAIN'}

\section{Ed. Louise Ryan and Wendy Webster}

Publisher: Aldershot, Ashgate

Year: 2008

Pagination: 224pp

ISBN: 9780754671787

Price: $\$ 99.95$ (USD)

This survey makes a case for the significance of studying trends related to gender and ethnicity within studies of migration. The collection of essays therein examine the history of migration in post World WarTwo Britain and, in so doing, draw on a range of sources, from archival research to interviews with migrants. In sum, the essays explore how the intersection of gender and ethnicity affects both the ways in which recent migrants to Britain have been represented as well as how migrants themselves construe their varied identities and experiences. Key here is not only the need to articulate the 
different experiences of migrating women and men but also to draw attention to how gender and ethnicity have shaped the experiences of migrants in Britain in the twentieth century. Considerable attention is paid to European migration in order to counter the superficial opposition which has been set up between immigrant/Black and British/White and, by extension, the assumption that Britain is an ethnically homogenous nation. Such superficial divisions have obscured the history of immigration prior to 1945, namely the movement of Irish and Jewish people.

The chapters are summarised as follows: Chapter one examines inter-war moral panics through the burgeoning relationships between Black men and White women as a result of an increasingly visible Black presence in Britain, as sustained through increased employment prospects for African and Caribbean men. There follows a more general look at the experiences of refugees in Europe between 1939 and 1950. In keeping with this context, chapter three focuses on the minutiae of the social circumstances and public attitudes towards the more intimate relations of British soldiers and German women.

Chapter four takes as its case study a consideration of Polishness in post-war Leicester and, in particular, male and female relations and gendered dynamics. Following a similar thematic approach, chapter five explores the impact of the view, historically and continued, that women were economically dependent on men both within the context of immigration policy and within the labour market between 1945 and 1975. Chapter six examines broader ramifications of family dynamics, namely the role of family in the formation of homeland, and the ways in which migrants become both 'strangers' and 'homecomers' as a result of their migrations.

In keeping with one of the original aims of the book, chapter seven claims that the majority of Irish migrants to Britain in the twentieth century were female and that Irish workers - both female and male - have been a major component of the British labour force during that period. Similarly, chapter eight is a reflection of some of the UK findings from a socioeconomic survey of the Spanish emigrant population, commissioned by the Spanish government.

The remaining chapters - nine through eleven - focus on constructions of masculinity in the experiences of Pakistani, Kurdish and East African Asian men.

\section{Also relates to:}

Economics and Globalisation

Employment

History

Migration, Immigration and the Refugee Experience

\section{MUSLIMS IN BRITAIN: RACE, PLACE AND IDENTITIES}

\section{Ed. Peter Hopkins and Richard Gale}

Publisher: Edinburgh, Edinburgh University Press

Year: 2009

Pagination: 224pp

ISBN: 9780748625888

Price: 119.99

This collection of short essays examines the situation of Muslims in Britain in a post 9/11 and 7/7 climate of anti-Muslim and anti-Islamic sentiment. To this end, it explores the politicisation of British Muslim identities as a result of the perceived clash between Islam and the 'West', and by extension, Islam versus 'democracy', 'security' and 'modernism'. There follows an in-depth look at how Muslims in Britain negotiate everyday situations, namely daily experiences of racism and the need to develop supportive networks within their communities.

The book starts by tracing the historical and demographic contours of Muslim presence in Britain as enabled through a spatial approach. This serves a dual function: Firstly, to counteract the sheer amount of negative stereotyping of Muslims in Britain, and secondly to highlight the diversity of the British Muslim experience.

Section one examines gender, place and culture. The resulting essays explore the following issues: the centrality of home in young Muslim women's construction of their identities; the impact of 
gender on educational experiences, aspirations and consequent interaction with the labour market; and the experiences of Muslim boys and their negotiations of masculinity and territory within neighbourhood spaces and schooling. All chapters address the ways in which gendered expectations and the social environment impact upon religious and cultural identities.

In section two - on landscapes, communities and networks - the author considers the everyday politics and interactions underpinning urban patterns of belonging and collective identity. The essays address the following themes: the history of social negotiations by British Muslims in the area of religious worship and education; the intersection between politics, public space and Muslim/Arab identities; and the importance of migration, mobility and pilgrimage in the lives of Muslims in Britain.

The third and final section reflects on the wider academic, popular and policy issues connected to Muslims in Britain. To this end, the chapters focus on a range of issues, from the formation of a Muslim identity and contemporary experiences of Islamophobia to an exploration of multiculturalism and a range of emancipatory politics adopted by British Muslims. Particular emphasis is paid to the latter issue as a means of counteracting the tendency to posit a monolithic unity to Muslim political and social identities. Here, the authors take issue with the resulting political pronouncements about the 'responsibilities' of Muslims in the wake of extremist attacks which, they claim, fail to acknowledge the wide-range of strategies adopted by Muslims in response to the changing socio-political climate of Britain.

Also relates to:

Criminal Justice and Racial Violence

History

Migration, Immigration and the Refugee Experience

Politics and Government

\section{STOLEN HONOR: STIGMATISING MUSLIM MEN IN BERLIN}

\section{Katherine Pratt Ewing}

Publisher: Chicago, Stanford University Press

Year: 2008

Pagination: 296pp

ISBN: 9780804759007

Price: $₫ 19.95$

'Stolen Honor' examines Germany's portrayal of Muslim women living in Europe as victims of male brutality who need to be rescued from oppressive male control. Such depictions present an implicitly negative image of Muslim men, who are conspicuous by their absence. As such, this study makes visible the continued stigmatisation - through misrepresentation and cultural stereotyping - of Muslim men in contemporary Germany. Attention is paid to the sub-population of Muslims in Europe and, in particular, Turkish immigrants and their descents now living in Germany.

The book is structured around two key questions pertaining to the processes by which such negative stereotyping has become naturalised within the German psyche, to the extent that the stigmatisation of Muslim men in contemporary Germany goes unrecognised, even by the most liberal of people. Building on the consequences from this, the author highlights the impact of such failures to recognise and address the social situation of Muslim men in Germany. The author goes on to highlight the combination of invisible and implicit processes which, combined through the enactment of national dramas of moral panic, have led to the widespread stigmatisation of Muslim men. This, in turn, has become bound up with the national and international imaginary and has, claims the author, been a contributing factor to recent changes in public policy and citizenship legislation, which are explored in more depth in the part two.

Part one is an investigation into the historical sources which have led to the current stigmatisation of Turkish men in contemporary Germany. The author contrasts cultural stereotyping with the everyday image of Muslim men and women living in Germany, juxtaposing the anonymous 'othering' of this community with individual attitudes and experiences. In so doing, this section highlights the processes at work in the reproduction and naturalisation of stigmatising images. 
Part two recounts a series of controversies which have resulted in widespread social panic and the further abjection of Muslim men in Germany. The first tells of the extensive media coverage following an honor killing in Berlin in 2005 , in which a young woman was murdered by her brothers because they objected to her non-traditional lifestyle. There follows a discussion of the controversy following the introduction of the "Muslim test" in 2006 - a guideline for determining the suitability of applicants for German citizenship. Lastly, this section highlights the 2000 controversy in which a conservative German politician proposed that 'Leitkultur' - namely, the social fantasy of German nationhood - be a standard for assimilation for Muslim men and women in Germany.

Also relates to:

Politics and Government

\section{STREET GANGS, MIGRATION AND ETHNICITY}

\section{Eds. Frank Van Gemert, Dana Peterson and Inger-Lise Lien}

Publisher: Devon, Willan Publishing

Year: 2008

Pagination: 286pp

ISBN: 9781843923961

Price: $₫ 23.75$

Produced by the Eurogang Network with the aim of developing a shared framework for studying street gangs, this collection of essays shifts attention away from the US and the allegedly uncoordinated study of American street gangs to instead present a more systematic approach to the study of European street gangs. Europe, claim the editors, provides more varied categories of marginalised populations in the realms of race, ethnicity, nationality and migration status, and henceforth is a more fruitful site of survey. The collection of essays that follow examine issues of marginality, socioeconomic disadvantage, youth culture, (im)migration and ethnicity which lead to gang formation and development across twelve European countries.

Part one starts by defining the origins of the phrase 'street gang' before charting the history of migration in Europe. Central this investigation is the relationship between ethnicity and gang formation, and the interaction between individual and collective (subcultural) identity. The essays in this section present a range of methods and approaches for the study of street gangs - from the comparison of American literature with European findings to an overview of sociological traditions for the study of youth formations in Europe. The latter essay draws attention to the ethical problems raised by such research and the consequent need to anonymise research locations during the presentation of research findings.

Part two consists of a series of case studies - from the position of Latin American youth in Barcelona and the formation of youth groups in the Netherlands to the history of racist skinheads in Moscow. Central to each is the need to prove or disprove the statement that the second generation of migrants usually become interested in and involved with gang activities.

Titled 'Ethnicity and Youth Gangs', part three explores the link between ethnic background and social circumstances, and charts gang involvement in terms of minority status, opportunitism, family attachment, school commitment and sense of self/cultural heritage. The essays in this section trace the distribution of gang membership in Sydney (Australia), Stuttgart (Germany), and across France, showing how gang involvement/affiliation is constructed as an act of pride and defiance in face of discrimination, inequality, exclusion and social injustice. Central to each case study is the significance of the transition from visible difference to social deviance.

The book concludes by exploring the issues and challenges presented by a consideration of migration and ethnicity when dealing with youth gangs. Looking at the situation of Pakistani gangs in Oslo (Norway), as well as the operation of criminal gangs in Gothenburg (Sweden), the essays in the final section explore the involvement of social institutions, such as schools, in the prevention and/or repression of gang activities. 


\section{UNEVEN ENCOUNTERS: MAKING RACE AND NATION IN BRAZIL AND THE UNITED STATES}

\section{Micol Seigel}

Publisher: Durham, Duke University Press

Year: 2009

Pagination: 408pp

ISBN: 9780822344407

Price: $\mathbf{1 8 . 9 9}$

Here, Micol Seigel charts the exchange of popular culture between Brazil and the United States during the inter-war period in order to trace the effects of such cultural exchanges on the construction of race and nation. Here, race and nation are viewed as mutually-tied rather than single entities in their own right, to be understood as an inter-relationship rather than in isolation. In this way, racial formation is dependent on nation(ality) and vice-versa, to form racialized national categories. To this end, the author claims, the dismantling of racial hierarchies first requires the dismantling of nationalism.

'Uneven Encounters' explores the ways in which people utilise transnational cultural exchange, subconsciously reworking lived ideas of race and nation. Particular focus is on the impact of advertising on the lives of Brazilians and North Americans and the ways in which they have shaped racialized national categories and contributed to international and transnational relations. The resulting chapters show examples of people who have crossed racial and national barriers, reinforcing or undermining notions of race and nation across a range of public, commerce, and popular culture. In sum, the following cultural forms are explored: advertisements, dance, music, vaudeville and other forms of popular stage performance, newspapers and public monuments. According to Seigel, these cultural forms transcend the national. For example, the coffee advertisements are made by both the US and Brazil; Brazilian dances are now widespread throughout the US; North American vaudevillians perform 'foreignness'; the newspapers are organs of the black Brazilian press, reporting on North American news; and lastly, the monument represents the potential of Brazilian history abroad.

Chapter one sketches the political and economic situation pertaining to the coffee trade both during and immediately following World War I. Central here is the cultural exchange between Brazil and the US, and the highly conscious ideological processes of advertising - namely, its production, circulation and consumption within a global market. Chapter two moves on to explore the travels of the Brazilian dance 'maxixe' and the ways in which the popular performance industry panders to an imperialist thirst for exoticism. In keeping with this, chapters three and four examine the ways in which cultural producers have utilised the alleged 'exoticism' of Brazil within artistic creation, professional advancement and political pursuits. Finally, chapters five and six move away from a focus on white North American subjects to highlight the effects of such forms of cultural formation and exchange on Afro-Brazilian and African American citizens.

Also relates to:

Arts, Literature and Sport

Economics and Globalisation

Politics and Government

\section{THE VEIL: WOMEN WRITERS ON ITS HISTORY, LORE, AND POLITICS}

\section{Ed. Jennifer Heath}

Publisher: Berkeley, University of California Press

Year: 2008

Pagination: 36opp 
ISBN: 9780520255180

Price: $₫ 14.95$

This collection of essays by women writers, academics and artists explores the socio-cultural and political aspects of the veil and notions of veiling. The resultant body of work represents the comingtogether of writers from a range of backgrounds and with diverse cultural experiences. Moving away from an emphasis on the veil as a symbol of tensions between Islam and the West, the contributors instead highlight the traditions surrounding the veil across a range of religious, historical and geographical contexts. The resultant accounts address the ways in which the veil-as-symbol has been misunderstood and the predominant ethnocentrism of critical accounts of the veil and of veiling to date.

The book starts by providing necessary background to the culture and politics of the veil and of concepts of veiling. Here, differing and sometimes contradictory meanings behind the veil are highlighted, from its figuration as a symbol of repression when enforced or forcibly removed to its becoming a symbol of resistance in face of prejudice and discrimination. The opening section goes on to provide a thorough background to the cultural uses and misuses of the veil. In so doing, the author challenges the vilification of women who veil by instead showing that it is, in fact, a combination of war, poverty, lack of education and neo-colonialism which have become the enemies of women's rights, not the veil. Thus, the beautiful and mysterious qualities of the veil are presented in stark contrast to its grotesque representation by the morbidly-fascinated West.

The anthology can be briefly summarised as follows. The essays in the first section examine the sacred aspects of the veil and the notion of the veil as an ancient custom and as a signifier of devotion. The second section moves on to explore the veil in relation to the physical and emotional body. The third, and final, section focuses on the socio-political aspects of the veil. Here, Muslim veiling is decentralised as a means of shifting attention away from the socio-political conflict of Islam to instead highlight the multiple processes at work under the guise of cultural veiling. In this way, the most interesting yet sadly sidelined aspects of the veil are revealed - namely, its metaphysical, mystical and erotic allure.

Section one examines the trauma of forced unveilings in the Middle East before moving on to highlight other uses of the veil besides those within Islam. To this end, the popularity of the veil is shown across a range of cultural and religious affiliations, including those within Papua Near East, India, Greece, and Eastern Europe. There follows a discussion of the dress codes of Hasidic women, the wearing of the Sari in India, the role of the habit in the Roman Catholic church, the Amish veil, and the experiences of an American Muslim woman. Section two explores the artistic life of the veil, from a look at Salome and the dance of the seven veils to concepts of Medieval veiling in Europe and veiling as viewed from an Arab Christian woman's perspective. The final section includes a discussion on female body hair in Iran and the representation of Islamic dress within newspaper cartoons.

\section{EDUCATION}

\section{BECAUSE OF RACE: HOW AMERICANS DEBATE HARM AND OPPORTUNITY IN OUR SCHOOLS}

Mica Pollock

Publisher: Princeton, Princeton University Press

Year: 2008

Pagination: $304 \mathrm{pp}$

ISBN: 9780691125350

Price: $\mathbf{2 0 . 9 5}$

'Because of Race' is an examination of racial inequalities in schools across the USA and, in particular, how young people of colour are denied educational opportunities on account of their race. The resulting work exposes conflicting analyses of harm and opportunity by a range of policy makers working within the present US education system. Of central concern are the resulting debates regarding educational opportunity and provision, in terms of resource allocation and discipline, as 
argued between parents, educators and Civil Rights Officers.

Pollock draws on her experiences working in the US Department of Education's Office for Civil Rights (OCR). During this time, she worked on a project which investigated whether the denial of key early learning opportunities to students of colour constituted a new area of racial civil rights work. She describes a particularly heated debate concerning whether the everyday treatment of students of colour fell into the category of racial discrimination and race-based harm. For Pollock, this translated into a dilemma - does she condone the denial of academic opportunity to children of colour? There follows an analysis of contemporary debates concerning the definition and achievement of racial equality and opportunity within contemporary North American education.

Section one-Rebuttal 1: Harms to Children of Colour Cannot Be Proved - explains the process of investigating discrimination complaints at the Office for Civil Rights. This transmits into a process of collecting 'evidence' pertaining to 'harm' in schools on account of race. It is of no surprise to learn that such an undertaking is complex, elusive and, ultimately, contradictory and controversial.

Section two - Rebuttal 2: Harms to Children of Colour Should Not Be Discussed - explores the resistance of local community and government to the Office of Civil Rights' 'prescribing' of assistance to children of colour during the process of complain resolution.

Section three - Rebuttal 3: Harms to Children of Colour Cannot Be Remedied - examines internal debates concerning the Early Learning Project, which explored daily opportunity provision to students of colour.

Lastly, section four - Rebuttal 4: Harms to Children of Colour are Too Small to Fix - describes how the efforts of the Office for Civil Rights were dismissed as doing little to deter counter structural or systematic inequality. The conclusion - 'Arguing toward everyday justice in the New Civil Right era' - shows how the New Civil Rights Era, also known as the Post-Civil Rights Era, characterises an era in which white Americans in particular resist specific measures to equalise opportunity for people of colour, even while sharing equal opportunity beliefs.

\section{BLACK BOYS CAN MAKE IT: HOW THEY OVERCOME THE OBSTACLES TO UNIVERSITY IN THE UK AND USA \\ CHERON BYFIELD}

Publisher: Stoke on Trent, Trentham Books

Year: 2008

Pagination: $168 \mathrm{pp}$

ISBN: 9781858564319

Price: $₫ 16.99$

In this timely and necessary work, Cheron Byfield reverses the overwhelming attention which has been paid to the underachievement of Black boys to instead focus on the notion of academic success. Breaking away from the negative stereotyping and the self-fulfilling prophecies created by this overly cited linkage, Byfield instead celebrates the ways in which Black male students overcome social barriers in order to enter into higher education. Interviewing forty university students from the UK and the USA, Byfield sets out to explore the factors influencing their academic success, their choice of and access to university and a breakdown of any social barriers faced. The book concludes with some suggested recommendations for schools and education policy makers.

Part one starts out by defining the keywords used ('race', 'Black' and 'social class') and outlining the proposed theoretical framework (which takes as its starting point Pierre Bourdieu's theory of Cultural Capital). There follows a summary of the UK and US educational systems. In Part two the obstacles encountered by the students are broken down into the following areas - social class (in the form of neighbourhood experiences and the quality of the schools attended) and parental involvement with the school system as well as the participants' own experiences of racism and the ways in which they negotiate their racial identity. There follows an in-depth exploration of the quandaries and selfmanaging effects of being a minority in a White dominated society, including the participants' own misbehaviour and negativity, and which lead to the development of a number of survival strategies. 
Part three centres on the factors which have contributed to the students' educational successes such as parental involvement and encouragement both in terms of learning at home and interacting with the school system, the students' own personal qualities (drive, hard work and determination etc) and, lastly, the role of teachers, community projects and religion in the students' lives. Whilst Byfield draws attention to the importance of positive representations and community support, the issue of religion is celebrated as an essential aspect of success but there is no attempt to question the ways in which this aspect may limit participant engagement. For example, whilst Byfield strives to represent the participants as a heterogeneous group in order to move away from the homogenising effects of negative stereotyping she comes close to reproducing the basis for this very resistance and fails to consider other factors which may conflict with religion or, as it is expressed here, Christianity - such as cultural affiliation or sexual orientation.

In Part Four attention is paid to the ways in which the participants navigate the university system, focusing on their perceptions and experiences, and drawing parallels between UK and US divisions of elite universities (such as Oxford and Harvard) and less selective institutions (Wolverhampton and Central Florida). The book closes by summarising the barriers faced, the strategies adopted and the factors which have contributed to the academic successes of the participants in order to identify areas of best practice within social policy development. This is a clear, concise and accessible piece of research which pulls no punches in starting to address the sheer public misconception and negative stereotyping surrounding young black male students and involvement in the UK/US education system.

Also relates to:

Culture, Identity, Gender and Relationships

Economics and Globalisation

History

Politics and Government

\section{BOTH SIDES NOW: THE STORY OF SCHOOL DESEGREGATION'S GRADUATES}

Amy Stuart Wells, Jennifer Kellison Holme, Anita Tijerina Revilla, and Awo Korantemaa Atanda

Publisher: Berkeley, University of California Press

Year: 2009

Pagination: $386 \mathrm{pp}$

ISBN: 9780520256781

Price: $₫ 16.95$

'Both Sides Now' comprises stories of former desegregation school students from a range of racial, ethnic and cultural backgrounds. The book is based on interviews with US graduates who attended desegregated high schools more than twenty-five years ago, between the mid 1960s and early 1980sas well as the educators and community leaders who were responsible for the desegregation policies. Claiming that the story of school desegregation in the US remains largely untold, the authors address this issue and chart both the benefits and limitations of such a move. In this way, the authors reverse the claim that school desegregation represents a failed social experiment to instead highlight the positive experiences of former students.

The remaining chapters highlight the desegregation school "experiment" of enrolling children from different racial backgrounds into the same schools. The White middle class graduates had mainly positive experiences to recount; but in contrast, the Black and Latino graduates found that mixing with White middle class students only served to emphasise the racial divide. Despite the good intentions behind the program, graduates of colour found the experience to be optimistic, yet ultimately disheartening as they became aware of the reality of racial difference and White privilege. Many graduates of colour claimed that this contrast became starker upon leaving the 'bubble' of racial harmony for the reality of racial prejudice and discrimination. As such, the book serves as window through which to examine the current state of racial politics in the US - the progress made and the distance still to go.

All former students told how the racial mix that they had been exposed to was merely confined 
to the school setting and did not extend into other aspects of their daily lives. They told of their shock and disappointment when they realised that their experiences within desegregationist schools were not sustained into adulthood. They cited the difficulties they faced adjusting to the outside world after being submerged in such an environment. In the main, however, the former students had mostly positive experiences and had much praise for the schools. They cite numerous anecdotes about how the experiences changed their attitudes and assumptions about racial and cultural differences. However, all former students acknowledge the limits of desegregation policies in terms of the failure to address the wider ramifications of racism and racial prejudice.

Also relates to:

Culture, Identity, Gender and Relationships

History

Politics and Government

\section{MULTILINGUAL LEARNING: STORIES FROM SCHOOLS AND COMMUNITIES IN BRITAIN Eds. Jean Conteh, Peter Martin and Leena Helavaara Robertson \\ Publisher: Stoke on Trent, Trentham Books}

Year: 2007

Pagination: 168pp

ISBN: 9781858563985

Price: $₫ 17.99$

Drawing on extensive consultations with both teachers and learners, 'Multilingual Learning' explores the affect of multilingualism in schools and communities across contemporary Britain.

Section one summarises the key issues and debates of key educational policies from the Second World War to the present. The remaining chapters in this section show the ways in which different communities respond to these policies and the specific teaching and learning spaces which have resulted. Of interest is the discrepancy between the celebration of diversity within government policy and a homogenising ideology which permeates within contemporary society. Key here is an analysis of the powerful ideological messages concealed within and which underpin legislative terminology. There follows an examination of the impact of language diversity on the development of community schooling and resulting contradictory responses to multilingualism in schools.

Section two - Learning in Three Languages in Home and Community-draws on learners' own experiences of being multilingual and contains the following case studies:

An interview with thirty-six children in a Gujerati Muslim community in North-East London in order to survey the daily experiences of children speaking in three languages - Gujerati, Urdu and English. A story of five bilingual children who are in the process of learning to read for the first time.

An example of the successful education of ethnic minority children and how Chinese minority children in particular become prominent among the high achievers of the British education system.

A survey comparing the experiences of Portuguese children taking Portuguese language classes with the experiences of Portuguese children in English mainstream schools.

A multi-language learning story in two Gujarati Complementary schools in Leicester

An example of the work of teachers in Complementary classes in Bradford, which aims to develop bilingual children's' knowledge of their home and community languages in order to raise their achievements in mainstream schooling.

Also relates to:

Culture, Identity, Gender and Relationships

History

Migration, Immigration and the Refugee Experience

Politics and Government

RACE AND CLASS MATTERS AT AN ELITE COLLEGE

Elizabeth Aries

Publisher: Philadelphia, Temple University Press 
Year: 2008

Pagination: $248 \mathrm{pp}$

ISBN: 9781592137251

Price: \pm 62.00

Based on interviews with fifty-eight students at Amherst College during the 2005-6 academic year, 'Race and Class Matters at an Elite College' traces student attitudes towards racial and economic diversity. Noting the diverse experiences of students from a range of class and racial backgrounds, the book examines the impact of social class and race on the college experience.

Chapter one charts the increasingly diverse nature of Amherst College, in terms of the changing demographics of its students; and yet, the author points out a marked discrepancy - whilst half of the current community of students can afford the $\$ 40,000$ a year fees, the remainder seek financial help from the institution. This is the starting point for an examination of the impact of class differences and race relations among an increasingly diverse student body, the result of recent changes in admission policies. The book seeks to address whether this growing diversity has resulted in an increased understanding of difference. In other words: what were the students' experiences of entering this environment?; what challenges did they face? Did such an environment challenge their assumptions of students from other class and racial backgrounds?

Chapter two describes how the participants were selected in terms of their backgrounds and prior experiences dealing with race and class issues. The remainder of the chapters present the results of the survey. After noting the students' varying levels of expectation and initial experiences of campus life, the author goes on to examine how students coped with class differences and being confronted daily by great disparities in wealth. A few themes emerge here-namely, the extent to which students desired to hide their class backgrounds and differences of attitude between lower and higher income groups. Chapter five explores the degree to which students separated themselves along class and racial lines and the extent to which they formed cross-race and cross-class relationships. There follows a look at shared values and how students negotiated class discrepancies.

The book moves on to explore the benefits students gained from diversity both inside and outside of the classroom. Whilst chapter six focuses on race, chapter seven views this in the context of class. In so doing, the author pays attention to whether, as a result of their experiences of campus life, students gained a new understanding of their own racial or class group and with other races or classes. Moreover, the author is keen to assess whether informal interactions helped to break down prior stereotypes and assumptions of class and racial difference. The book closes with an interesting reversal of the college's policies of race and class - whilst students are asked to adjust to the culture of Amherst College, can the College, in turn, adjust in order to incorporate a more diverse student body?

\section{RACE AND EDUCATION: POLICY AND POLITICS IN BRITAIN}

\section{Sally Tomlinson}

Publisher: Maidenhead, Open University Press

Year: 2008

Pagination: 248pp

ISBN: 9780335223077

Price: $₫ 24.99$

'Race and Education' discusses the key education issues in Britain from the 1960s to the present. The author claims that, at present, both policy makers and the British media place unwarranted attention upon the dress codes of particular faith and religious communities rather than focusing on urgent problems in the realms of education, housing and employment. According to the author, issues surrounding segregation, social poverty, national identity, racism and multiculturalism should be at the forefront of educational policy concerns. The author goes on to state that attempts by the education system to incorporate racial and ethnic minorities are contradictory and flawed, and reflect a broader climate of racial ambivalence and hostility. The concerns of British education systems are set within a wider framework of recent social changes and political events. Key here is the need to address the success rate of integration and education around ethnic and racial diversity within British 
education.

The introduction summarises the waves of immigration in Britain from the 1960 s to the present, which can be divided into two distinct groups - the first comprising settlers from the former British Empire who answered the demand for British labour immediately following the Second World War; the second consisting of people seeking asylum following war, civil strife and human rights violations in their home countries as well as economic migrants who have been arriving since the mid 1990 . According to the author, developments of this kind account for the fact that the British education system currently lacks political support and the relevant policies for enabling a more diverse and fair society.

The chapters are divided according to decade (ranging from 1960 to 1997) and cover the following issues: ideology and politics; general educational policy and educational issues; and practices relating to race and ethnicity. Chapter one summarises the political ideologies which have led to the assimilation of immigrants at the lower levels of a capitalist economy and which have given rise to the situation that immigrants are forced to undertake work which white workers are reluctant to do. The next chapter examines anti-immigrant agitation. Chapter three explores the economic, social and racial divisions which gave rise to the riots of Hackney (London), Toxteth (Liverpool) and Handsworth (Birmingham). here follows a discussion about legislative control concerning migrants and asylum seekers. Chapter five examines the impact of New Labour on race relations and racial tensions in Britain between 1997 and 2003. Chapter six concerns the wars in Afghanistan and Iraq and the resultant increased antagonism between Muslims and non-Muslims in contemporary Britain, which has led to the scrutiny of Islamic dress within British schools. The book concludes by summarising the current political and educational situation surrounding the absorption of minority youth into a majority society.

Also relates to:

Culture, Identity, Gender and Relationships

History

Migration, Immigration and the Refugee Experience

Politics and Government

\section{HEALTH AND SOCIAL CARE}

\section{HISTORY}

\section{HARRIET TUBMAN: MYTH, MEMORY AND HISTORY}

\section{Milton C. Sernett}

Publisher: Durham, Duke University Press

Year: 2007

Pagination: $424 \mathrm{pp}$

ISBN: 9780822340737

Price: \pm 75.00

This book investigates the interplay of history and myth within the collective American memory and, in particular, the numerous retellings of the story of Harriet Tubman (1822-1913). Tubman, a conductor on the Underground Railroad, has become a international icon and is today widely celebrated as a symbolic Black leader, a figurehead for a politics of anti-slavery, and role model for both feminist and African-American communities alike. Known by her contemporaries as 'the Moses of her people' and a 'Black Joan of Arc', Tubman unsuccessfully sought compensation for her years of service as a Union Army spy and nurse during the American Civil War.

In this unconventional biography, Milton Sernett strives to separate the Tubman the 'lady' from Tubman the 'legend' in order to focus on the processes by which this woman became a cultural icon. In so doing, Sernett plucks fact from fiction in an attempt to highlight the myths which prop up the legend and which fuel the collective American imagination. As such, Sernett is interested in the difference between biographical details and collective memory - namely the ways in which 
Tubman has been remembered. Of particular interest here is the way in which Tubman has become 'overdetermined' and the ways in which a historical figure, such as Tubman, is mediated by recent and contemporary bias. In other words, attention is given to the ways in which Tubman has been used by 'special interest groups' in order to lend a historical trajectory to contemporary (identity) politics.

Although the chapters are constructed thematically, the structure of the book mimics the chronology of Tubman's life.

Also relates to:

Culture, Identity, Gender and Relationships

Politics and Government

\section{MIGRATION, IMMIGRATION AND REFUGEES}

\section{ASIAN DIASPORAS: NEW FORMATIONS, NEW CONCEPTIONS}

\section{Eds. Rhacel S. Parrenas and Lok C. D. Siu}

Publisher: Palo Alto, Stanford University Press

Year: 2007

Pagination: $320 p$ p

ISBN: 9780804752435

Price: $\$ 24.95$ (USD)

This collection of essays examines the movement and migration of Asian populations on a global scale through the lens of diaspora. Here, diaspora is defined as an 'ongoing and contested process of subject formation embedded in a set of cultural and social relations'. It is examined in relation to the ways in which different ethnic groups claim Asia as both their 'real' and 'imagined' homeland and site of dispersal. Drawing on a range of historical and ethnographic studies, emphasis is placed on human experiences of diaspora in order to draw attention to the interaction of everyday life and larger systems of social and political control.

Attention is paid to the underlying structures of inequality that create diasporic communities as well as the resultant cultural barriers both by homeland and host country. This feeds into a more general discussion about the broader issues of neo-liberalism, globalization and transnationalism. In sum, the book explores five key issues: the recognition of inter-Asian strife; the persistence of nation state; the salience of race, ethnicity, gender and sexuality; the forces of labour, colonialism and globalisation; and the centrality of culture in considerations of race and ethnicity.

The introduction provides detailed information pertaining to the social and historical conditions which have led to the re-emergence of diaspora, transnationalism and globalisation at the close of the twentieth century. According to the authors, this is, in part, due to dramatic transformations of recent decades: developments in technology/communication; global political and economic shifts, the adoption of neoliberal policies and principles of deregulation, privatisation and materialisation; and a dramatic increase and extensive reach of global migration.

Emphasising diaspora as a process and a form of resistance, 'Asian Diasporas' represents both an intellectual inquiry and a political intervention. The book is structured around two key questions: 'What are the cultural and social factors that enable the production of diasporic identifications?'; and 'What are the specific political and economic conditions that frame these different migrations?' The resultant body of essays examine the following themes in reply: notions of cultural authenticity; psychic injuries of displacement; double displacement and national exclusion; and the intersection of ethnicity, gender and sexuality. The adjoining case studies include: the impact of Chinese labour migration to Latin America; the experiences of Japanese Brazilians in Japan and Brazil; contemporary arranged marriages in Vietnam; and labour migration to the British West Indies.

\section{Also relates to:}

Culture, Identity, Gender and Relationships

Economics and Globalisation

Politics and Government

Science and Technology 


\section{ASYLUM DENIED: A REFUGEE'S STRUGGLE FOR SAFETY IN AMERICA}

\section{David Ngaruri Kenney and Philip G. Schrag}

Publisher: Bekerley, University of California Press

Year: 2008

Pagination: $360 \mathrm{pp}$

ISBN: 9780520261594

Price: $₫ 12.50$

'Asylum Denied' tells the story of political refugee, David Ngaruri Kenney, and his experiences of immigration control in the US. The story starts in Kenya with Kenny leading a peaceful protest with his fellow farmers against the Kenyan government's treatment of local tea farmers and the exploitative agricultural policies. He was consequently arrested, imprisoned and tortured. Whilst in solitary confinement, Kenney endured the constant threat of violence, intimidation and execution. Upon release he was subject to increasing levels of police surveillance and consequent threats. The book also details how, with the help of a group of US Peace Corps Volunteers, Kenney fled to the US and considers the additional concern of the human rights violations of immigration controls and the subseuqent and all-too-real impact on the lives of those most in need of its protection.

The book starts by comparing US government's turning away of immigrants who face persecution and death with the US government's refusal to grant asylum to Jewish migrants seeking refuge from the Holocaust, many of whom subsequently died at the hands of Nazi Germany. Such a stark comparison serves to highlight the continued plight of persecuted people who seek refuge and asylum abroad.

Subsequent chapters chart the role of the 1980 Refugee Act, which was designed to accommodate refugees into the US. However, the authors show how, since the 1990s, new amendments have meant that applicants awaiting asylum would not be eligible to work. This was followed by further restrictions on immigration in a post 9/11 climate and increased suspicions about fraudulent applications and the threat of terrorism. Thereafter, book details the sheer bureaucracy which characterises US immigration controls, as found within the Department of Homeland Security, the Board of Immigration Appeals, the US Court of Appeal, and the Department of State.

The book examines Kenney's plight both within Kenya and at the hands of the US government. The following dilemma highlights the ridiculousness of the situation. Here, the authors highlight the fact that governments which abuse human rights often prevent their dissidents from leaving their voluntary because they fear scrutiny from abroad. Thus, victims of persecution - like Kenney - are forced to leave their country by alternative means. However, despite acknowledging the severity of human rights abuses in Kenya, countries like the US have made it a felony to enter any state on an illegal passport even if it was necessary in order to flee torture or persecution. In such cases, asylum is revoked. Thus, the very system of granting asylum fails to understand and address the realities of asylum.

Also relates to:

Culture, Identity, Gender and Relationships

Politics and Government

\section{DIASPORAS}

Roger Waldinger, William Rodarmor and Stephane Dufoix (trans. William Rodarmor),

Publisher: Berkeley, University of California Press

Year: 2008

Pagination: $160 \mathrm{pp}$

ISBN: 9780520253605

Price: $\$ 21.95$ (USD)

'Diasporas' provides a critical introduction to the concept of 'diaspora', charting both its intellectual history and its political relevance; and shows dispora to be more than just an academic tool. Stéphane Dufoix shows how diaspora is lived out as a social practice - a means of enabling state control and, 
conversely, a means of enacting social change.

Drawing on a range of case studies of diasporic people - including Jewish, Armenian, African, Chinese, Greek and South Asian Indian - Dufoix develops a conceptual framework for thinking about the relationship between migrants and their homelands (which are here referred to as 'dispersed populations' and 'referent origins'). He claims that current theorising around diaspora fails to describe the relationships between migrants and their referent origins, and urges for the need to establish a broader and more complex analytical framework.

The book starts by discussing the evolution and development of diaspora as viewed through alternate conceptual frameworks. In this context, diaspora emerges as a term with a number of definitions, namely - any phenomenon of dispersion from a place; the organisation of an ethnic, national or religious community in one or more countries; a population spread over more than one territory; places of dispersion and displacement; and a connection with a real or imagined homeland. The discussion then moves on to highlight the changing nature of diaspora and raises a number of questions pertaining to the perceived connections between migrants and their homeland, state and fellow migrants. To this end, the author draws on the examples of both Jewish and African experiences of diaspora within a particular socio-historical context.

Chapter two - 'Space of Dispersion' - highlights the dilemma that dispersion, by its very definition, relies on a unified departure point but that no such common point exists when we talk about dispersed populations in the sense that migrants come from a multitude of referent origins rather than a single homeland. This paradox is explored in more detail in the case of Greek, Indian, Chinese and Armenian migrants.

Towards the end of chapter two, Dufoix breaks the notion of diaspora down into seven stages: A population - namely the statistical ensemble of dispersed people and their descendents; an ethnocultural community existing in several countries; and ethnic population within a single country; a particular migratory pattern; a historical/psychological condition; a geographical area of dispersion; and a subset of a larger diaspora. There follows a brief discussion of diasporic illusions pertaining to essence, community, continuity, identification, differentiation and historicity.

Chapter three examines the ways in which diasporic people maintain connections when 'abroad', and summarises his findings into four models - 'centroperipheral', 'enclaved', 'atopic', and 'antagonistic'. Thereafter Dufoix examines the notion of nostalgia in relation to homeland before concluding with a discussion about the future of diaspora and diasporic studies.

Also relates to:

Culture, Identity, Gender and Relationships

Politics and Government

\section{PROTRACTED DISPLACEMENT IN ASIA: NO PLACE TO CALL HOME}

\section{Ed. Howard Adelman}

Publisher: Aldershot, Ashgate

Year: 2008

Pagination: 282pp

ISBN: 9780754672388

Price: $₫ 60.00$

A protracted displacement situation describes the situation in which refugees are held in displacement camps indefinitely and without recourse to basic human rights. Drawing on a number of case studies, 'Protracted Displacement' examines the long-term protracted refugee situations in Nepal, Thailand, Bangladesh, Sri Lanka, Afghanistan and Iraq.

Chapter one provides in-depth theoretical context surrounding the conceptualisation of refugees as products of membership problems, on one hand, and as universal rights holders, on the other. This provides the necessary background for the remaining chapters.

Chapter two describes the situation in which 105,000 Bhutanese refugees have lived in Nepal for the last eighteen years and that the situation is not set to change in the immediate future and that, despite fifteen sets of negotiation between Bhutan and Nepal, not a single refugee has returned 
home. The author explores how the situation of the Bhutanese in Nepal shifted attention away from the development of a durable solution discourse towards a programme of refugee resettlement. Chapter three builds on this discussion to outline the protracted displacement situation on the ThaiBurmese border. The next chapter centres on a debate on whether the forced displacement of people from Burma to Thailand and Bangladesh necessitates the need of intervening military to implement a personal responsibility to protect $\left(\mathrm{R}_{2} \mathrm{P}\right)$. There follows a discussion of the international protraction regime in the case of the Rohingya refugees in Bangladesh and the resulting prioritising of certain refugee groups over others.

The situation of Sri Lanka forms the subject of chapter five, which examines the notion of conflict-induced internal displacement and the resulting dilemmas of protection. Related to this, chapter six focuses on Afghan refugees in Iran, Pakistan and those who have been internally-displaced within Afghanistan. Chapter seven focuses on the two million refugees and 2.2 million internallydisplaced persons, as produced by the US forces in 2003. The author explores whether resettling abroad would represent a viable and durable solution to this protracted situation.

The concluding chapter (chapter 8 ) reviews the situation of protracted displacement as it relates to the case studies outlined above. Here, the author emphasises the need to consider the local socio-political situation of each case study rather than seeking universal solutions. Central to this is an examination of the politicised and militarised contexts which give rise to both displacement and its potential solutions. In this regard, the author makes an important question, namely how humanitarian agencies can more effectively respond to protracted displacement and enhance the protection of populations living in prolonged limbo. To this end, three different but interrelated dilemmas are highlighted - between state sovereignty and human security; between natural selfinterest and universal morality; and between durable solutions and enduring solutions, which have perpetuated the plight of refugees and internally-displaced persons.

Also relates to:

History

Politics and Government

\section{SLEEPWALKING INTO SEGREGATION?' CHALLENGING MYTHS ABOUT RACE AND MIGRATION}

Nissa Finney and Ludi Simpson

Publisher: Bristol, The Policy Press

Year: 2009

Pagination: 218pp

ISBN: 9781847420077

Price: 114.99

This book dismisses claims that British society is sleepwalking its way into segregation and conflict, and rejects fears about immigration, racial division and dangerous cultures as nothing more than moral panics. In so doing, Finney and Simpson challenge arguments that Britain is dangerously segregated and that immigration is bad for Britain's existing relations. In short, the authors set out to prove that such pessimism concerns are unfounded.

Re-examining statistics pertaining to immigration, Finney and Simpson show the ways in which data has been manipulated, leading to misleading predictions about race relations and the future of racial integration. They show how, when properly investigated, claims about immigration and race transpire as exaggerations at best. By focusing on evidence which has been ignored in the process of perpetuating these myths, the authors strive to present a more optimistic future for race relations in Britain.

The book starts by discussing how and why ethnicity has come to be defined and measured, 'outing' the historical association between statistics and race eugenics. What transpires is an unearthing of sensationalism, both in terms of how 'ethnicity' is used within the media and this filters through into society, sustained as it is within a climate of xenophobia and racism, naïve conservatism and fears of change, resulting in the scapegoating of minorities during economic recession and war 
in Islamic countries. Chapter two questions the meaning and value of race data and, in particular, the historic and continued uses of ethnic group data, before strategising more positive uses.

The remainder of the book attempts to deconstruct the myth that immigration is a 'problem', correcting notions that growing minority populations are creating a housing crisis, that minority populations 'fail' to integrate, and that minority populations contribute to spatial segregation ('ghettoisation'). In the last instance, the authors raise the ides of white-flight and residential separation as leading factors. In a particularly satisfying argument, the authors challenge the notion that cities are becoming 'minority white' by claiming that this very concept is racist, assembling as it does white supremacy and privilege in its allusion of white as 'more' than an ethnic or racial category. The final chapter attempts to understand why these myths are so persistent and suggests alternative ways of thinking about race and immigration.

\section{Also relates to:}

Culture, Identity, Gender and Relationships

Economics and Globalisation

History

Housing and Planning

Politics and Government

Social Theory

\section{SURVIVAL OF THE KNITTED: IMMIGRANT SOCIAL NETWORKS IN A STRATIFIED WORLD Vilna Francine Bashi \\ Publisher: Chicago, Stanford University Press \\ Year: 2007 \\ Pagination: $344 \mathrm{pp}$ \\ ISBN: 9780804740890 \\ Price: $€ 58.50$}

'Survival of the Knitted' is an ethnographic survey of West Indian Social networks in New York, London and the West Indies. Vilna Francine Bashi examines the ways in which migrant life is structured in order to achieve optimal opportunity and support, both financial and emotional. Bashi develops a new theory of transnational immigrant network organisation, which consists of a "hub-and-spoke" model. Here, a veteran migrant (the hub) provides encouragement, support and mentoring to newcomer migrants (the spokes) during their movement from their home to host country and consequent resettlement. The author stresses the importance of such networks for shaping a newcomer's experiences during the emigrational process. To this end, the research builds on extensive interviews with nearly one hundred newly-migrated Caribbean people in London and NewYork whose experiences are in keeping with the "hub-and-spoke" migrant networking model.

According to Bashi, to date there is scant information about the formation and perpetuation of migration networks, especially in terms of its ability to explain other factors influencing migration. As such a new theory was required to help explain the phenomenon whereby someone would move to a place they did not feel compelled to visit with someone with whom they had little contact with prior to migrating. Moreover, such a theory would help to then explain why that person feels at home solely on account of the goodwill gestures of other migrants. Here we come to the central thesis of the book, namely the importance of the "hub" - i.e. the person who lends assistance to many others in the network's configuration.

The book outlines the role of the network in the development of migration and mobility. In this sense, the immigrant social network can be viewed as an important catalyst for the initiation and development of new forms of migration. To this end, this piece of research shows how migration is a phenomenon rooted in the decision making processes of networks and in the key connections that are formed between individuals therein. In turn, the formation of valued relationships can be interpreted as an example of social capital on the basis of the significance of the resources that the network connections bring to the network members. Key to this is a 'culture of reciprocity' which is governed through unwritten rules of obligation, gift-giving and repayment. The remainder of 
the book highlights network achievements in terms of geographic mobility, mobility within labour markets, mobility in housing, social support, and ethno-racial solidarity-building against racism.

Also relates to:

Culture, Identity, Gender and Relationships

Employment

Housing and Planning

Social Theory

\section{POLITICS AND GOVERNMENT}

\section{LIBERATED TERRITORY: UNTOLD LOCAL PERSPECTIVES ON THE BLACK PANTHER PARTY}

\section{Eds. Yohuru Williams and Jama Lazerow}

Publisher: Durham, Duke University Press

Year: 2009

Pagination: 312pp

ISBN: 9780822343264

Price: $₫ 16.99$

'Liberated Territory' is a follow-up to the editors' previous collection of essays - 'In Search of the Black Panther Party', which provided an overview of the Black Panther Party and its legacy. In this collection, Williams and Lazerow focus on the impact of the Black Panther Party across the United States to show how the party's ideologies and strategies were taken up and subsequently modified by a range of local communities. In bringing together this collection of essays, the editors aim to initiate a scholarly body of work pertaining to 'Panther Studies' which takes local history and a historiographical survey as its starting point.

In the introduction, the authors provide a historical overview of the formation of the group and the socio-political climate pertaining to the founding aims and objectives of the group. There follows an in-depth survey of the demographic and ethnographic make-up of the various states in which the group and its consequent splinter groups set-up. The book moves on to examine the strained relationship between party members and the local police which was manifested through police corruption and brutality, violent clashes, lootings and shootings. However, this is kept in brief as a result of the need to shift attention away from any sensationalising of the group in order to instead focus on the ways in which the Panthers fought everyday experiences of racial harassment, prejudice and stigma. In other words, rather than dwelling on the alleged disturbances created by the group, the authors are instead keen to highlight the positive and empowering outcomes of the coming together of the Panthers. In so doing, the authors highlight the national appeal of the Panthers and their putting into practice the notion of 'thinking globally, acting locally'. To this end, contributors' chart the significance of the group and the pro-activity of its members in the areas of housing, employment, education and recreation. Particular attention is paid to the federal initiatives of the group, which can be summarised as contributing to urban renewal, democratic politics, and anti-poverty work.

The first chapter summarises the founding aims and principles of the Black Panther Party. This is followed by geographically-specific considerations which highlight the diverse nature of the group's work - chapter two focuses on Oakland, Boston and New Bedford 'riots' of 1970; chapter three centres on the Alabama Black Liberation Front; chapter four highlights the situation of the Black Panther Party in Detroit; lastly, chapter five focuses on Milwaukee as a case study for signalling the wider ramifications of the group.

Also relates to:

Criminal Justice and Racial Violence

Culture, Identity, Gender and Relationships

Politics and Government 


\title{
SOCIAL THEORY
}

\author{
ETHNICITY AND INEQUALITY IN HAWAII \\ Jonathan Y. Okamura \\ Publisher: Philadelphia, Temple University Press \\ Year: 2008 \\ Pagination: 256pp \\ ISBN: 9781592137565 \\ Price: $\$ 26.95$
}

Here, Okamura shows how ethnicity, rather than race or class, structures social relations in Hawaii. As a result, he attributes greater emphasis on cultural differences among ethnic groups rather than more obvious physical differences, such as hair or skin colour, which, he claims here, have less social significance. In this way, Okamura focuses on ethnicity rather than race to show how the former category is the primary structuring principle of social relations, claiming that the groups which comprise island society - namely, Filipino Americans, Samoans, Whites and Puerto Ricans - are socially constructed as belonging to ethnic rather than racial groups.

Okamura addresses the fact that, since the 1970s, Hawaii has not figured in theoretical discussions of race and ethnicity in the US. The author claims that this is due to historical and contemporary exaggerations about the allegedly tolerant nature of the Island's ethnic relations. He goes on to demonstrate how ethnic stereotypes have been used against ethnic minorities and how these groups have forged new identities in an attempt to challenge their allegedly 'subordinate' position. In so doing, the author challenges the widespread notion that Hawaii shows a model of ethnic equality and harmony to instead show that this is far from true.

The book starts by recounting the decision by the University of Hawaii to increase its tuition fees and the adverse affect this has on underrepresented minorities, such as Filipino Americans and Native Hawaiians. The author claims that such a move contradicts the University's own policy to provide equal access to education. This is explored in more depth in chapter four - "Educational Inequality and Ethnicity" - in which it is stated that that policy decisions like this are manifestations of institutional discrimination against ethnic minorities on the basis that these groups are subject to unequal or unfair treatment through these policies.

In the discussion which follows, Okamura interprets ethnicity as being at the intersection of ethnic identity and social structure and that the difference therein represents the framing of inequality. He moves on to show how ethnic identity formation can be used to subvert ethnic inequality. Whilst chapter two presents demographic information about Hawaii's ethnic groups in order to highlight social and cultural differences, chapters three and four explore the scope and nature of ethnic inequality in Hawaii through an in-depth socio-economic and educational analysis. Chapters five through to seven move on to focus on ethnic identity construction among a range of ethnic groups across Hawaii. Finally, the book concludes with a general analysis of how ethnic inequality is perpetuated in Hawaii, formulating strategies for reducing - eliminating - ethnic inequality through the fostering of a collective socio-economic mobility among disadvantaged ethnic minorities

\section{Also relates to:}

Culture, Identity, Gender and Relationships

Economics and Globalisation

Education

History

Politics and Government 